\title{
Ecosystems for smart cities: tracing the evolution of governance structures in a dutch smart city initiative
}

\author{
Ward Ooms ${ }^{1} \cdot$ Marjolein C. J. Caniëls ${ }^{1}$ (D) - Nadine Roijakkers ${ }^{1}$. \\ Dieudonnee Cobben ${ }^{1}$
}

Published online: 8 February 2020

(C) The Author(s) 2020

\begin{abstract}
Smart cities use integrated information and communication technology in order to help their citizens and organizations deal with the challenges of urbanization, safety, and sustainability. Smart cities need complex forms of governance involving a great variety of actors. The aim of this study is to illustrate how elements of governance structures in smart city ecosystems evolve over time, and to understand in which way these elements enable or inhibit the success of such ecosystems in different phases of evolution. We draw on the ecosystem literature and the smart city literature to identify governance aspects relevant to projects with multiple stakeholders. We illustrate our framework with extensive empirical evidence from an in-depth single case study of a smart city initiative in The Netherlands. We find that the use of specific governance elements varies across the phases of evolution of the smart city ecosystem. In the initiation phase, governance structures aimed at strengthening the internal relations are key. In this phase, elements such as trust, commitment, and common goals are important as they help to create a common ground. In the growth phase, the ecosystem focuses on establishing external relations with other parties, such as competitors and suppliers. In this phase, governance elements such a co-creation strategy and a dedicated organization for promotion gain importance, as these elements facilitate communication with external parties.
\end{abstract}

Keywords Smart city $\cdot$ Governance structures $\cdot$ Ecosystem $\cdot$ Evolution

Acknowledgements: Our study partly draws on interview data gathered for: Cobben, D., \& Roijakkers, N. (2019). The Dynamics of Trust and Control in Innovation Ecosystems. International Journal of Innovation: IJI Journal, 7(1), 1-25. For the current study new data has been added and the total dataset was recoded and reanalyzed on aspects that are relevant for the current study.

Marjolein C. J. Caniëls

Marjolein.caniels@ou.nl

Extended author information available on the last page of the article 


\section{Introduction}

The interest in smart city development is growing (Komninos and Mora 2018). Studies exploring the phenomenon broadly clarify that their interest follows from strong global trends of urbanization that pose challenges to growing cities in terms of ensuring continued safety, efficiency, and sustainability (e.g. Lee et al. 2014; Girardi and Temporelli 2017). The smart city concept is seen as a way to facilitate and satisfy citizens', companies', and organizations' needs in this regard, by using integrated information and communication technologies (ICTs) (Girardi and Temporelli 2017). Current knowledge about smart city development is dispersed across different literatures, such as the ecosystem literature (e.g. Cobben and Roijakkers 2019; Stam 2015: Pop et al. 2018), and the smart city literature (e.g. Schaffers et al. 2011; Lee et al. 2014; Mora et al. 2017; Fernandez-Anez et al. 2018).

In a comprehensive study, Lee et al. (2014) develop a framework to analyze smart cities along six dimensions: (1) urban openness, (2) service innovation, (3) partnership formation, (4) urban proactiveness, (5) smart city infrastructure integration, and (6) smart city governance. Each of these dimensions of smart cities needs further empirical investigation to understand which characteristics can make for smart cities to develop and function. Specifically the last dimension, smart city governance, is identified as a key driving force to enable smart city development (Lee et al. 2014), but smart city governance is also an issue that is not yet fully understood (Fernandez-Anez et al. 2018). Not only scholars, but also policymakers, have identified the importance of governance. The Dutch government, for example, calls for a better understanding of how smart cities have to be governed at the local level (Rijksoverheid 2018). Lee et al. (2014) argue that smart cities' governance structure may "bring together multiple stakeholders to drive growth and foster use of smart services" (p.84). Hence, governance is required to offer guidance to the other smart city dimensions, and to provide room for smart cities to flourish on these dimensions.

Although contemporary literature about smart cities has identified governance structures to be an important driving force (e.g., Lee et al. 2014; Fernandez-Anez et al. 2018), this line of investigation is still in its infancy. What is clear though, is that the governance mode of smart cities is not merely one of a market economy, but that governance is a complex ordeal. Smart city governance needs to work with (and affect) processes at various levels (Deakin 2014; Leydesdorff and Deakin 2011): national and local policies, corporate strategies of the firms involved, academic leadership at the universities that partner in the initiatives, and so on. Field research by Angelidou (2017) highlights that smart cities themselves are preoccupied with the ICTs that enable their activities, at the expense of equally important attention to policy and governance. However, a few previous studies did focus on smart city governance. First, several studies consider the role of specific actors in smart city governance, such as the role of universities (e.g. Ardito et al. 2019; Ferraris et al. 2018), and the role of human resource management practices in large firms who are involved in several smart city projects at the same time (Ferraris et al. 2019). Second, previous studies have explored very early stage governance in smart city projects, focusing on partner selection from the perspective of the firms involved (Sandulli et al. 2017) and on top-down strategy development (e.g. Letaifa 2015). Despite these previous in-depth explorations of smart city governance, there is a knowledge gap when it comes to understanding (a) smart city 
governance across the lifespan of projects (research to date is focused on specific stages of smart city development), and (b) the interaction between several kinds of partners typically involved in smart cities (rather than the one-sided perspective of a single type of actor, usually city, university, or firm, also paying attention to more bottom-up approaches).

In addition to contemporary smart city literature, other literature strands may also be used to explore smart city governance. Particularly, ecosystem literature is suited to analyze smart cities, and there are several studies of smart cities that are part of the ecosystem literature (e.g. Angelidou 2014; Letaifa 2015). The reason is threefold. First, the smart city resembles different kinds of ecosystems (e.g. innovation, knowledge) in many of its characteristics, e.g.: the diversity of actors involved, goals ranging from knowledge-related goals, to economic goals, to social goals, and the territorial scope (Scaringella and Radziwon 2018). Second, the ecosystem literature holds findings on governance, particularly regarding the orchestration (or leadership) of ecosystems, that may be informative to smart cities. Third, the literatures share the same challenges when it comes to developing an understanding of what Scaringella and Radziwon (2018) call "life cycle guidelines for practitioners and [...] scholars" (p.74), or in other words: What do policy makers and managers in these ecosystems and smart cities need to do in order for their projects to be sustainable in the long run?

Hence, there is a need for research that considers smart city governance from a more holistic point-of-view (accounting for all kinds of potential partners involved), as well as research that integrates findings from studies across different literatures. Moreover, current knowledge lacks in-depth understanding of the conditions that enable smart city development, which calls for insights from experiments with smart city ecosystems and their governance (Schaffers et al. 2011; Lee et al. 2014). Put simply, little is known about how smart city governance is organized in practice. This is unfortunate, because such a line of inquiry would allow us to identify the conditions that may enable or inhibit the success of smart city development. Scholars have identified that the gap between theoretical contributions and the sector-wide implementation of governance has to be bridged, and they therefore call for exploratory empirical research (e.g. Lee et al. 2014; Bolici and Mora 2015; Fernandez-Anez et al. 2018).

In this study, we intend to contribute to the smart city literature by adding to the current understanding of factors that could enhance the effectiveness of governance structures. Specifically, we examine the use of a wide variety of governance factors that have been identified in the literature to stimulate smart city development (e.g. Lee et al. 2014; Fernandez-Anez et al. 2018), and investigate how their use changes as smart city initiatives evolve over time. We pursue the following research question:

How do elements of governance structure evolve over time in smart city ecosystems and in what way do they enable or inhibit success of such ecosystems in specific phases of evolution?

To answer the research question, we conduct a single case study relying on extensive interview data, observational data, and secondary data sources. In our case study we analyze a smart city initiative called "De Kleine Aarde". This initiative operates as an ecosystem of various partners experimenting with innovative smart solutions for environmental and social sustainability, and the implementation thereof. The case study data offers a rich perspective on the use of different governance structures over time within one smart city ecosystem. 
We contribute to theorizing about smart city governance by augmenting the smart city literature with novel understanding of how elements of governance structures evolve over time, as well as understanding of how these elements influence the development of a smart city. By building upon the extant literature on the governance of ecosystems, this research provides an initial attempt to connect the fields of ecosystem literature and smart city literature.

The paper continues with a theoretical framework that directs our analyses of governance structures for smart city initiatives (Section 2). In Section 3, we detail our methodological approach, case study context, and procedures for data analysis. The case study results are reported in Section 4. We end the paper with a discussion of the theoretical implications that follow from the results and set out a number of directions for future research (Section 5).

\section{Theoretical framework}

\section{Governance for smart cities}

As a result of external events such as rapid urbanization, climate change, and increasing population growth, governments have started to develop projects that aim to create smart cities. This is a type of city that is able to satisfy the needs of its citizens and organizations by using ICTs (Girardi and Temporelli 2017; Kumar et al. 2018). The goal of a smart city is to "create sustainable value for citizens, employees, shareholders and other stakeholders" (Lee et al. 2014, p. 83), and thereby drive cities' overall growth and development. The success of a smart city depends on the collective integration of technological, governmental, institutional, and transitional components (King and Cotterill 2007; Eremia et al. 2017). To integrate these different components successfully, governance models should be structured and able to design and implement participatory decision-making processes for diverse types of actors in the city (Novotny et al., 2014; Eremia et al. 2017).

These diverse types of actors are represented in an ecosystem. The smart city consists of many different ecosystems that aim to provide solutions to specific problems (Kumar et al. 2018). Ecosystems consist of various individuals and organizations that have to collaborate in order for projects to succeed. Every actor present within an ecosystem has individual interests and reasons to contribute to the ecosystem. Within ecosystems, the interrelations between infrastructure, society, and institutions are considered (Fernandez-Anez et al. 2018). Ecosystems for innovation can be distinguished from other forms of collaboration, such as alliances, portfolios, and networks, by a number of characteristics. Considering smart cities as ecosystems, the ecosystem consists of a wider variety of partner types than many other forms of collaboration. For example, smart city ecosystems typically include citizens, as opposed to merely organizations. These types of partners are uncommon to other forms of interorganizational collaboration. Smart city ecosystems are also more service-oriented than other collaboration forms, as their core goals relate to the transformation of the lives of individuals in cities and the improvement of societal well-being at large. The partnerships in ecosystems exist longer than in some other collaboration forms, because their common goals (e.g. reducing energy usage within a neighborhood or increasing safety 
in the city) cannot be reached in short periods of time due to their complexity. Finally, in ecosystems, partners are more likely to engage in joint strategizing and shared value creation and appropriation at the level of the system rather than at the level of the individual partners (Leroi-Werelds et al. 2017; Oh et al. 2016).

Governance is particularly important to smart city ecosystem success, due to the generally diverse set of partners. For these ecosystems to attain their goals, it is paramount that all parties, including citizens, have the opportunity to collaborate and develop innovations for the smart city. In order to understand and identify the relevant elements of a governance model that is able to activate and align all relevant actors within a smart city ecosystem, we draw on studies from different strands in the literature, which have studied and conceptualized various factors that are used to govern collaboration. Specifically, we start by exploring the ecosystem literature (e.g. Cobben and Roijakkers 2019; Stam 2015; Pop et al. 2018) and then consider the smart city literature (e.g. Lee et al. 2014; Schaffers et al. 2011; Fernandez-Anez et al. 2018). Within the smart city literature the importance of governance has been mentioned, though it is not fully understood yet. Within the ecosystem literature, governance has been investigated in more detail. Therefore, both strands of literature are combined to have a better understanding of governance within a smart city context.

In order to better understand the way ecosystems work, Stam (2015) introduces an ecosystem model. In this model, governance can be seen as the 'systemic conditions' in ecosystems that enable the creation of value from 'framework conditions'. Framework conditions constitute the potential to create value in ecosystems, for example, local demand, a shared culture, and/or a physical infrastructure. In other words, where there are opportunities for ecosystems to create value, the 'linking pin' needed to capitalize on these opportunities and transform them to value is governance (i.e. 'systemic conditions'), according to the ecosystem model. Without governance as its linking pin, ecosystems will not be able to create value despite their exogenous and endogenous potential to do so. Systemic conditions include networks, leadership, finance, talent, knowledge and support services (Stam 2015). Some of these conditions relate directly to governance: Networks, leadership, and support services. In addition to this ecosystem model, other works within the ecosystem literature have identified related factors of ecosystem governance. Notably, Cobben and Roijakkers (2019) have identified the importance of factors such as communication, transparency, expectation management, leadership, trust, and commitment for the effectiveness of governance structures. Each of these factors influences the value creation and capturing within the ecosystem by mitigating the risk of opportunistic behavior and motivating parties to arrive at agreements about collaboration. Different combinations of these trust- and/or control-based governance factors influence ecosystem effectiveness in different phases of evolution.

There is a fairly recent set of studies about smart cities as a phenomenon, from which one may distill further governance factors of interest. Notably, in their overview study, Lee et al. (2014) collect existing insights on governance for smart cities and identify six elements of smart city governance structures. Their work considers first the role of a rather formal governance structure, departing from (1) an overall smart city strategy that is to be developed and supported by (2) smart city leadership (i.e. "the mayor's office plus different agency's directors within the city", Lee et al. 2014, p.84). This strategy is translated into (3) smart city principles and (4) performance criteria 
(Lee et al. 2014). Smart city principles refer to municipal ordinances about city planning and urban development projects (Lee et al. 2014), which cities specify in such a way that these may stimulate smart city related planning and development as prescribed by the smart city strategy. Performance criteria should be used for performance measurement for the city agencies implementing the smart city policies (Lee et al. 2014). It is likely that different performance criteria are devised for different actors in the initiative, as Lee et al. (2014) also propose the introduction of certain standardized (5) processes and assigned roles for the development and management of the smart city initiative. Day-to-day operations of the smart city are overseen by (6) a dedicated organization tasked with promoting the smart city initiative (Lee et al. 2014). All these factors and the way they are (or are not) implemented can have different implications for the effectiveness of governance structures. Another two studies have addressed governance for smart cities in particular: Schaffers et al. (2011) and Fernandez-Anez et al. (2018). Both studies emphasize the key role of governance to ensure actor involvement in the smart city. Furthermore, both Schaffers et al. (2011) and Fernandez-Anez et al. (2018) characterize governance in smart cities as a process of strategizing. That is, the former study calls for cooperation and co-creation strategies, while the latter study calls for a comprehensive strategy for smart city projects to guide both collaboration choices and innovation processes in such cities. It is only with such strategies for innovation and collaboration that the smart cities may generate innovative solutions to urban challenges.

\section{Integrating perspectives on governance}

It follows directly from our literature review that governance is important for smart cities. Across the ecosystem and smart city literatures scholars have found that governance is a 'linking pin' between opportunities for smart city developments and utilization of such opportunities (e.g. Stam 2015; Lee et al. 2014). Hence, governance is required to face urban challenges by using the smart city concept. There are, however, two important differences between these literature strands.

The first difference pertains to perspectives on leadership for smart cities. The ecosystem and the smart city literatures identify a different sort of leader(ship). In ecosystem literature the leadership role is attributed to an entrepreneur (Stam 2015), facilitated by public leaders who strongly promote entrepreneurships' importance (Isenberg 2011). By contrast, in the smart city literature the leadership role is attributed to one or more individuals' working for or with city government (Lee et al. 2014). We propose that an integration of these perspectives on leadership from the two different literatures most accurately captures the nature of leadership in smart cities. That is, because of the diverse nature of partners working together in smart cities, it is likely that leadership is distributed amongst a group of individuals and/or organizations in ecosystems, which may include entrepreneurs or citizens, as well as individuals working for governmental or other public organizations.

Another difference between the ecosystem literature and the smart city literature is the focus on trust and control. The ecosystem literature devotes significant attention to understanding trade-offs between control-based and trust-based governance mechanisms. Specifically, the ecosystem literature tends to focus on a combination of trust and control, for example, via the use of commitment to create a sense of mutual trust 
alongside performance measurement. In the smart city literature, the focus is on using governance as a way to stay in control, for example, via the use of performance measurement.

Despite these differences in perspectives of both literatures on specific elements of governance, the integration of these literatures yields an analytical framework that can be used to study governance in smart cities. The output of governance is the activities in and by the smart city initiative, which in turn affect the development and evolution of smart cities (Fig. 1).

\section{Dynamics of governance structures}

One of the objectives of our study is to gain understanding about changes in the use of specific governance structure elements as smart city initiatives evolve over time. We draw on the literature on ecosystems (Thomas and Autio 2014; Moore 1993) and clustering (Brenner and Schlump 2011) to identify three phases of ecosystem evolution. Although different names are used for phases throughout literatures, scholars "more or less seem to agree on the existence of three distinct phases" (Brenner and Schlump 2011, p.1365). We adapt these phases to suit smart city ecosystems, and the phases are: initiation, growth, and maturity. Initiation is a phase in which an ecosystem is nascent, that involves sense-making, resource-gathering, and establishment of organizational structures for the ecosystem (e.g. Thomas and Autio 2014). It is sometimes referred to as the phase of ecosystem birth (Moore 1993). Growth is a phase in which the ecosystem expands rapidly, both in terms of its activities and its size (e.g. Thomas and Autio 2014). The ecosystem may attract more partners and may also face some competition (Thomas and Autio 2014). This phase is sometimes referred to as the expansion phase (Moore 1993; Brenner and Schlump 2011) or the momentum phase (Thomas and Autio 2014). Maturity is a phase in which an ecosystem has obtained

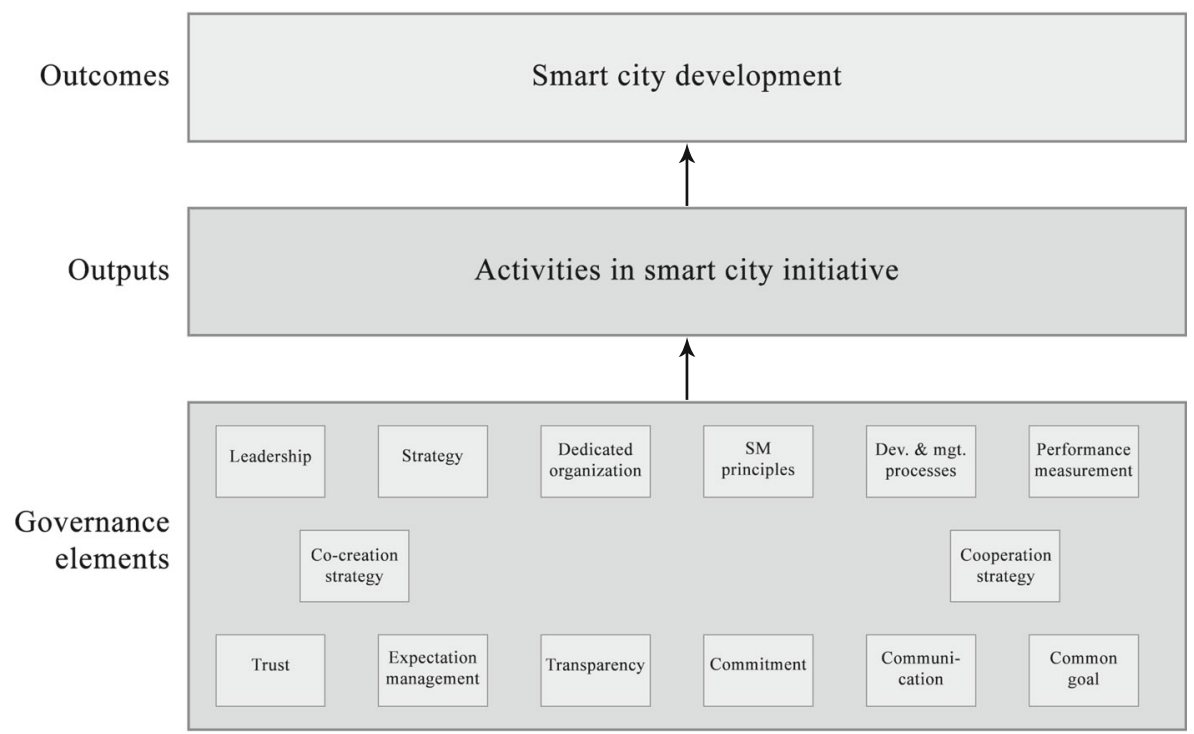

Fig. 1 Governance affecting outputs and outcomes of smart cities (adapted from Stam 2015) 
"socio-political and cognitive legitimacy" (Thomas and Autio 2014, p.7). In other words, the ecosystem is fully established, and directs its activities less to growth and more to control and value appropriation, but also to continued value creation. This phase is also referred to as the control phase (Thomas and Autio 2014) or the phase of leadership and self-renewal (Moore 1993).

Table 1 provides an overview of different governance structure elements (factors) that have been proposed in the ecosystem and smart city literatures to be essential to effective governance structures in ecosystems. These factors can be grouped into three higher order categories, namely (1) factors that concern the orchestration of the smart city initiative, (2) factors that involve community building and strengthening of the ties between community members, and (3) factors that result from the effective working of other parts of the governance structure and enable further growth and strengthening of the system. Plusses in Table 1 identify the prominence of each factor in different phases, on basis of the literature.

During the evolution of the system different factors will gain importance. In the initiation phase, governance is oriented at orchestration, by the generation of a common value proposition (strategy-setting aided by leadership). During initiation, partners have to develop their willingness to be dependent on other ecosystem partners, i.e. trust should be built. Initiation also entails the gathering of resources and the start-up of operations. The first operations are typically very limited; only restricted access to each other's resources is given. A first attempt is made at developing rules, and competitive activity is generally still insignificant. Hence, according to the literature (Table 1), mainly factors that pertain to orchestration, while also building trust (a resultant factor), are used in the initiation phase of the initiative. In the growth phase, governance focuses on managing larger numbers of participants and increasing competition. Strategies for cooperation and co-creation are developed. Thus, most attention is directed to factors that strengthen the community, for instance the common goals are now stressed in order for them to be understood by all parties (Cobben and Roijakkers 2019; Robards et al. 2011), and there is attention for managing the expectations of various actors about their own role and the results from cooperation (Caniëls and Romijn 2008a, 2008b). Communication between parties and cooperation strategies may result in trust and commitment to the initiative. Finally, in the maturity phase, ecosystem governance is yet again concerned with orchestration, but now focused on other factors thereof, such as the development of control and value appropriation. Whereas in the growth phase the emphasis shifted towards community building, during the maturity phase factors that are linked to orchestration of the system gain importance again.

\section{Method}

\section{Case study context}

In the Netherlands, the smart city concept has gained interest from firms, citizens, policy makers, public organizations and academics. This uptake in interest is a global trend. Initially, attention was mostly devoted the application of ICTs to 'smarten' cities (Jansen 2016; Albino et al. 2015). Yet smart city initiatives in the Netherlands and 
Table 1 Different governance structure elements (factors) for smart cities

Evolution of the smart city initiative*

\begin{tabular}{|c|c|c|c|c|}
\hline \multicolumn{5}{|l|}{ Higher order concept } \\
\hline Factor & Description & Initiation & Growth & Maturity \\
\hline \multicolumn{5}{|l|}{ Orchestration } \\
\hline Leadership & $\begin{array}{l}\text { Supporting and directing individuals to contribute } \\
\text { to common goal (Stam 2015; Lee et al. 2014; } \\
\text { Hollands 2008; Lam 2005; Angelidou 2014; } \\
\text { Letaifa 2015) }\end{array}$ & + & + & + \\
\hline Strategy & $\begin{array}{l}\text { Strategy that is regularly revised and reviewed } \\
\text { (Lee et al. 2014; Angelidou 2014; Letaifa } \\
\text { 2015) }\end{array}$ & + & + & + \\
\hline $\begin{array}{l}\text { Dedicated organization for } \\
\text { promotion }\end{array}$ & $\begin{array}{l}\text { Publicly recognized organization that is } \\
\text { responsible for the promotion of the smart city } \\
\text { (Lee et al. 2014; Angelidou 2014) }\end{array}$ & & & ++ \\
\hline $\begin{array}{l}\text { Development and } \\
\text { management processes/ } \\
\text { support services }\end{array}$ & $\begin{array}{l}\text { Standard planning and development processes, } \\
\text { clear roles, actor involvement, supply of } \\
\text { support to ecosystem (Stam 2015; Lee et al. } \\
\text { 2014; Mortara et al., 2009; Pop et al. 2018; } \\
\text { Shah et al., 2006; Ferraris et al. 2019) }\end{array}$ & + & + & ++ \\
\hline Smart city principles & $\begin{array}{l}\text { Overview of principles based on municipal } \\
\text { ordinances related to planning and } \\
\text { development that have to be fulfilled (Lee } \\
\text { et al. 2014; Angelidou 2014; Deakin 2014) }\end{array}$ & + & + & \\
\hline Performance measurement & $\begin{array}{l}\text { Clear description of criteria on how to measure } \\
\text { performance (Lee et al. 2014; Shah et al., } \\
\text { 2006; Pop et al. 2018) }\end{array}$ & & + & ++ \\
\hline Cooperation strategy & $\begin{array}{l}\text { Strategy specifically focusing on the collaboration } \\
\text { with universities, companies, and governments } \\
\text { (Schaffers et al. 2011; Fernandez-Anez et al. } \\
\text { 2018; Angelidou 2014) }\end{array}$ & & + & + \\
\hline Co-creation strategy & $\begin{array}{l}\text { Strategy specifically focusing on the co-creation } \\
\text { with citizens (Schaffers et al. 2011; } \\
\text { Fernandez-Anez et al. 2018; Angelidou 2014; } \\
\text { Letaifa 2015) }\end{array}$ & & + & + \\
\hline \multicolumn{5}{|l|}{ Community building } \\
\hline Common goal & $\begin{array}{l}\text { Presence of a common goal that is understood } \\
\text { and supported by the group (Cobben and } \\
\text { Roijakkers 2019; Robards et al. 2011; Sandulli } \\
\text { et al. 2017; Kale and Singh, 2009) }\end{array}$ & + & + & + \\
\hline Communication & $\begin{array}{l}\text { Exchanging information (Cobben and Roijakkers } \\
\text { 2019; Ferraris et al. 2019) }\end{array}$ & + & ++ & ++ \\
\hline Transparency & Openness (Cobben and Roijakkers 2019) & + & + & + \\
\hline Expectation management & $\begin{array}{l}\text { Managing the variety of expectations within a } \\
\text { collaboration (Cobben and Roijakkers } 2019 \text {; } \\
\text { Caniëls and Romijn 2008a, 2008b; Ferraris } \\
\text { et al. 2019) }\end{array}$ & + & ++ & \\
\hline \multicolumn{5}{|c|}{ Resultants, enabling further growth and development } \\
\hline Trust & $\begin{array}{l}\text { Willingness to be dependent on others (group or } \\
\text { individual) (Cobben and Roijakkers 2019; } \\
\text { Sandulli et al. 2017) }\end{array}$ & ++ & + & + \\
\hline Commitment & $\begin{array}{l}\text { Willingness to contribute, to put effort in } \\
\text { something (Kale and Singh, 2009, Cobben and } \\
\text { Roijakkers 2019; Stam 2015; Sandulli et al. } \\
\text { 2017) }\end{array}$ & + & + & ++ \\
\hline
\end{tabular}

*: Plus signs indicate to what extent factors are considered in relation to a specific phase of ecosystem evolution in reported literature. A single plus indicates that factors are linked to a phase in some reported literature, whereas a double plus signals links of this factor to a phase in most reported literature. Absence of a plus indicates no links throughout the reported literature. 
globally have shifted or expanded their scope beyond the purely technological dimension, e.g. to sustainability goals (living lab Groningen) or social inclusion goals (living lab Eindhoven) (Ministerie van Infrastructuur en Milieu 2016). At the same time, within the Dutch context, the smart city phenomenon is subject to some criticism. Critiques are particularly questioning the speed with which smart city concepts may realistically be expected to be implemented in cities, arguing that "the smart city is not built in a single day" (Zeemeijer 2017), and calling into question (cyber) security risks associated with the smart city (NOS 2016). Nonetheless, data obtained from the Ministerie van Infrastructuur en Milieu (2016) points to several initiatives experimenting with smart city concepts in the Netherlands.

Our study focuses on such an experiment with the smart city concept, an initiative called "De Kleine Aarde" (translated: "The Small World"). This initiative has existed since 1972 in several forms and with a variety of purposes. However, today it can be considered an experiment with the smart city concept. After going bankrupt in 2011 and subsequent unsuccessful experiments between 2011 and 2014 due to financial setbacks, the initiative was renewed completely in 2015. The municipality of Boxtel was the initiator, and it sought the support of several public and private partners in redeveloping "De Kleine Aarde". An ecosystem was developed that involved a very diverse group of actors amongst which were several schools for secondary vocational education, the local public water authorities, regional healthcare providers, hospitality entrepreneurs, and one of the largest Dutch stock-listed construction firms. The goal of the initiative is to smarten the city in terms of sustainability and social inclusion. Although the technological dimension of the smart city is not at the core of the experiment, the ecosystem does develop projects in the field of smart technologies, e.g. the integration of these technologies to build a circular apartment complex and the use of technology for marketing. According to its vision document, the aim of "De Kleine Aarde" is to create a sustainable, self-providing community by focusing on four different programs: The built environment, bio-based techniques and food, energy transition, and social transition. Interestingly, despite the recent global developments that sparked the interest in smart cities, "De Kleine Aarde's" goals today are not far from those with which visionary and initiator Sietze Leeflang founded the community back in 1972. In those days, "De Kleine Aarde" was already aimed at developing smallscale techniques to disburden the environment. Currently, the ecosystem is located at a designated site in the municipality of Boxtel. The location fulfills educational purposes, offers inspiration to interested citizens, provides testing facilities (living labs), and focuses on the reintegration of people that are distanced from the labor market. In 2016, it started hosting a food garden, as well as an organization that aims at building a network for partners in the region who are interested in sustainability and citizen participation.

\section{Research design}

We apply an exploratory single case study design to examine the evolution of the governance structure in a smart city ecosystem. The selected case is an exemplary case for three reasons (Eisenhardt and Graebner 2007; Yin 2013). First, this individual case is one of only a few examples of experiments with a smart city initiative that has existed for several years in the Netherlands, and is unique in the sense that it pursues 
sustainability and social inclusion goals at the same time. Second, because we intend to study evolution of governance in the initiative, it is helpful that information is available that allows us to clearly demarcate steps in the evolution of this case and its governance and construct timelines for analysis. Third, the size of the case is manageable, such that it allows for rich data to be collected about the phenomenon, yet safeguards the research from a common pitfall of theory building from case study research, which is overcomplexity (Eisenhardt 1989; Yin 2013).

Our approach can be characterized as one of studying innovation as a process-asobserved (Garud et al. 2017), as we examine the selected case in order to identify, map, and detail the sequence of events that has unfolded as this ecosystem experimented with different approaches to governance over time. This design allows us to explore in which ways various dimensions of smart city governance are employed in practice. It enables us to answer questions related to our research question about the evolution of governance practices over time and their impact on the success of the smart city ecosystem. Thereby, our study aims to lay the groundwork for future studies of a more evaluative nature (Yin 2013).

\section{Data collection and data analysis}

We triangulated data from various primary and secondary sources. The core method of data collection was semi-structured interviews, conducted between May 2018 and November 2018. In total, we collected data from eleven interviewees who were directly involved in the governance of the ecosystem: board members, members of the core team, and general partners of the ecosystem. We distinguish two phases of the ecosystem's development based on the literature of ecosystem evolution in order to identify the evolution of the governance structure across these phases (Fig. 2). We identify the initiation phase (phase 1) as the period during which the ecosystem consisted of a core team (responsible for the daily operations) and a number of other ecosystem partners, together preparing for the establishment of a more formal ecosystem. We identify the growth phase (phase II) as the period after which a foundation (organization) was established, and a foundation board was erected to fulfill more

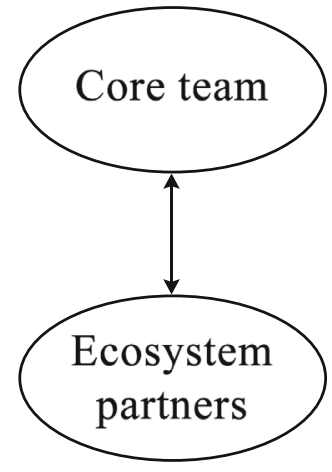

Phase I

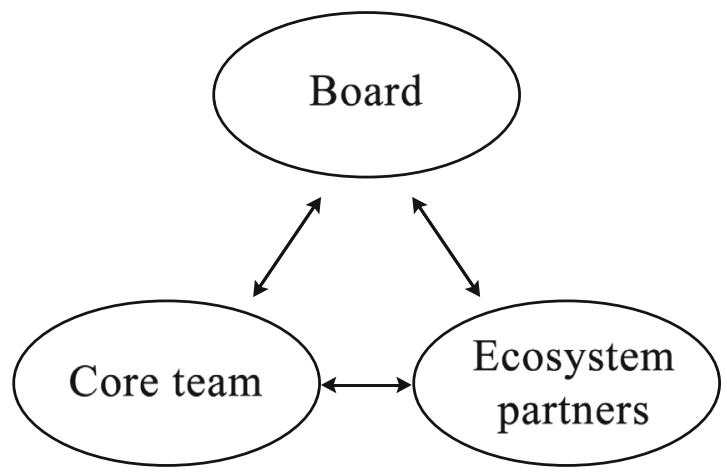

Phase II

Fig. 2 Governance structures two phases of development 
strategic tasks. Generally, the interviewees held senior or middle management positions in their organizations. The sample includes interviewees from several firms, public organizations (including the municipality and a regional public investment fund), and several educational institutions, all involved as partners in the ecosystem (Table 3). One interviewee, formally tasked with leading the ecosystem, was interviewed twice (once at the start of data collection and once to round up data collection) in order to double check insights obtained through other interviews. The semi-structured interviews had a retrospective nature, and were designed to cover specific themes related to the governance of the ecosystem in four components. First, we collected general information about the interviewee's organizational background and his/her introduction to the ecosystem. Second, through several open-ended questions we inquired about the interviewee's experience of the relevant outputs of the ecosystem so far. Third, the major component of the interview guide focused on questions pertaining to all kinds of aspects related to the ecosystem's governance structure. We asked questions such as "Did you experience the same leader during the whole trajectory or was the leadership fulfilled by different persons?", "How diverse is the group of partners in your view?", "How do you experience the leader, is there a real leader?", "Was the goal of the collaboration determined collaboratively or was it in place when you joined?", and "Are there any shared cultural elements?" These questions (and others) were used as opening questions and depending on the interviewee's reply, follow-up questions were administered to gather more detailed information and illustrative examples. Fourth, we asked questions that required interviewees to recall critical events in the ecosystem's evolution, such as: "How do you handle conflicts?" and "What were your intentions to join?" All interviews were tape recorded and all recordings were transcribed. The average interview duration was $40 \mathrm{~min}$.

Additional primary data was collected in observations of two discussion sessions between the interviewees. Additional secondary data ranged from data obtained via the initiative's website (e.g. press releases, social media messages), to an internal vision document, and data obtained via a lexical search in selected news media.

We developed and used a case study database consisting of field notes, observation notes, case study documents, and interview data in order to enhance reliability (Gibbert et al. 2008; Yin 2013). From this database, we analyzed the data using a starting list of codes from our theoretical framework with initial ideas about potentially important governance elements derived from the literature (Table 4). The coding was checked by different experts to increase the construct validity. From the coded data, we composed a case summary detailing the evolution of governance practices in the ecosystem over time. This summary aimed to condense the meaning of the larger transcription into an identification of the main themes that emerged from the interviews (data reduction). Then, the data was coded manually, and eventually displayed in a table (Miles and Huberman 1994; Saunders et al. 2009).

\section{Results}

The results of our analysis of the smart city ecosystem experiment "De Kleine Aarde" are summarized in Table 2. The table shows the theoretical factors (e.g. leadership, strategy) organized along the three higher-order concepts (orchestration, community 
building, and resultants), underlying ecosystem governance as put forward by the existing literature and integrated within our theoretical framework. We provide illustrative excerpts from our case study data (i.e. interview quotes and excerpts from secondary data), in relation to each of the governance factors and for each phase of the ecosystem's evolution. Furthermore, Table 2 provides information as to the enabling or inhibiting influence of governance factors on the effectiveness of the ecosystem and its partners in terms of reaching the set goals. The findings will be discussed for each phase separately.

\section{Initiation phase}

With respect to the leadership dimension, the interviewees note that although there is one partner who coordinates and facilitates the ecosystem (also supported by strategy documents), this partner is not regarded as a leader. One interviewee notes that there is a person who concentrates on the vision for the common goal, next to a facilitator/ supporter. The focus in this phase is more on coordination and facilitation rather than true leadership.

With respect to strategy, a vision document was developed in which the partners collaboratively framed their common strategy. Despite the vision document and the fact that partners saw eye-to-eye at the time in relation to the higher-level goal of the ecosystem (interviewee 4 mentions to this end: "The higher goal has been developed in collaboration; everyone committed"), partners did not feel aligned with respect to their strategy. Some partners feel that the vision document was written behind a desk with a select group of people rather than in collaboration and with everybody involved.

Smart city principles constitute another, contextual factor for effective governance of smart city ecosystems, and refer to the presence of a stimulating regulatory environment for smart city planning and development that is supported and enacted by relevant governments and related agencies. Based on information from secondary sources this dimension can be categorized as an enabling factor of the effective governance of this particular smart city ecosystem. Specifically, at the regional level, smart city principles and guidelines have been developed and the necessary funds have been secured to enable support for the initiative. This is in line with national smart city principles that are being developed by the Dutch government.

At the time of initiation, ecosystem partners had started to develop a cooperation strategy in the form of a partnership agreement. An interviewee noted that this partnership agreement functioned as a letter of intent for him (Interviewee 10). To enable the development and presence of a cooperation strategy, key persons were invited to share dinners and meet, in order to stimulate the development of trust and commitment among partners. Despite the fact that the development of a cooperation strategy commenced, there were still quite a few steps that had to be taken in order for this strategy to enable effective governance, such as the effectuation of contracts and the insurance of commitment to the contracts among all partners.

When the "Kleine Aarde" was started, the common goal was described in an internal strategy development document. There was no consensus among participants as to whether this was a participatory project or not. Some interviewees felt that the common goal was developed with all ecosystem partners ("The higher goal has been developed collaboratively." (8)), whereas other interviewees felt that they were not able 
离

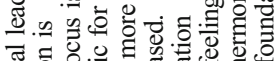

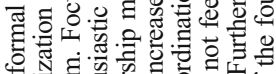

응

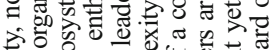

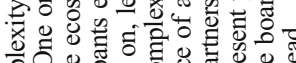

웅 \&

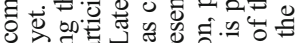

高

字记

.

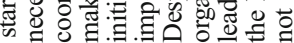
艺

$\infty \overline{\mathrm{d}}$

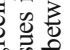

क्षे

ㅂ.

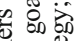

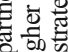

然

흉 을

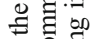

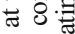

害宫言

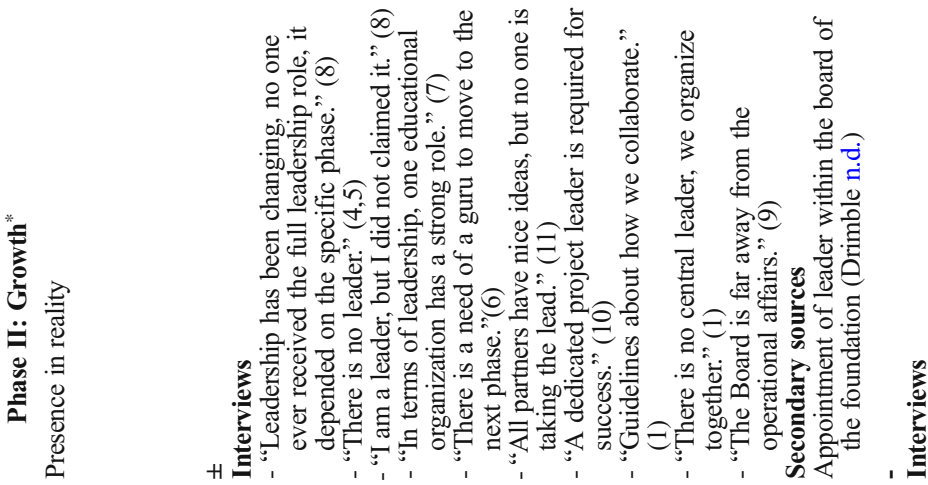

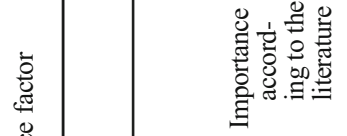

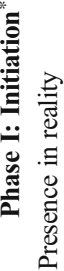

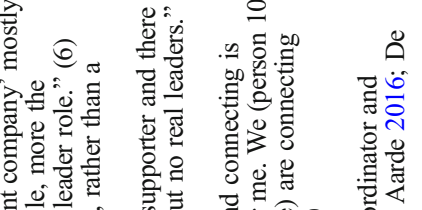

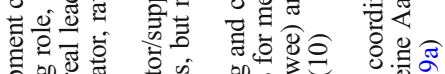

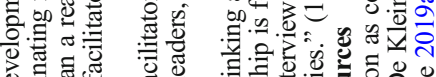

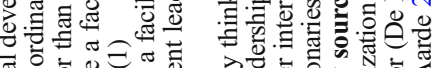

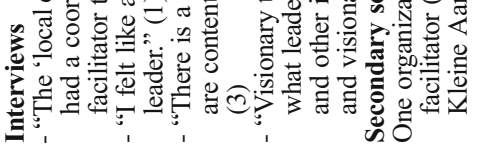

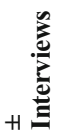

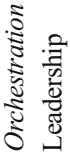




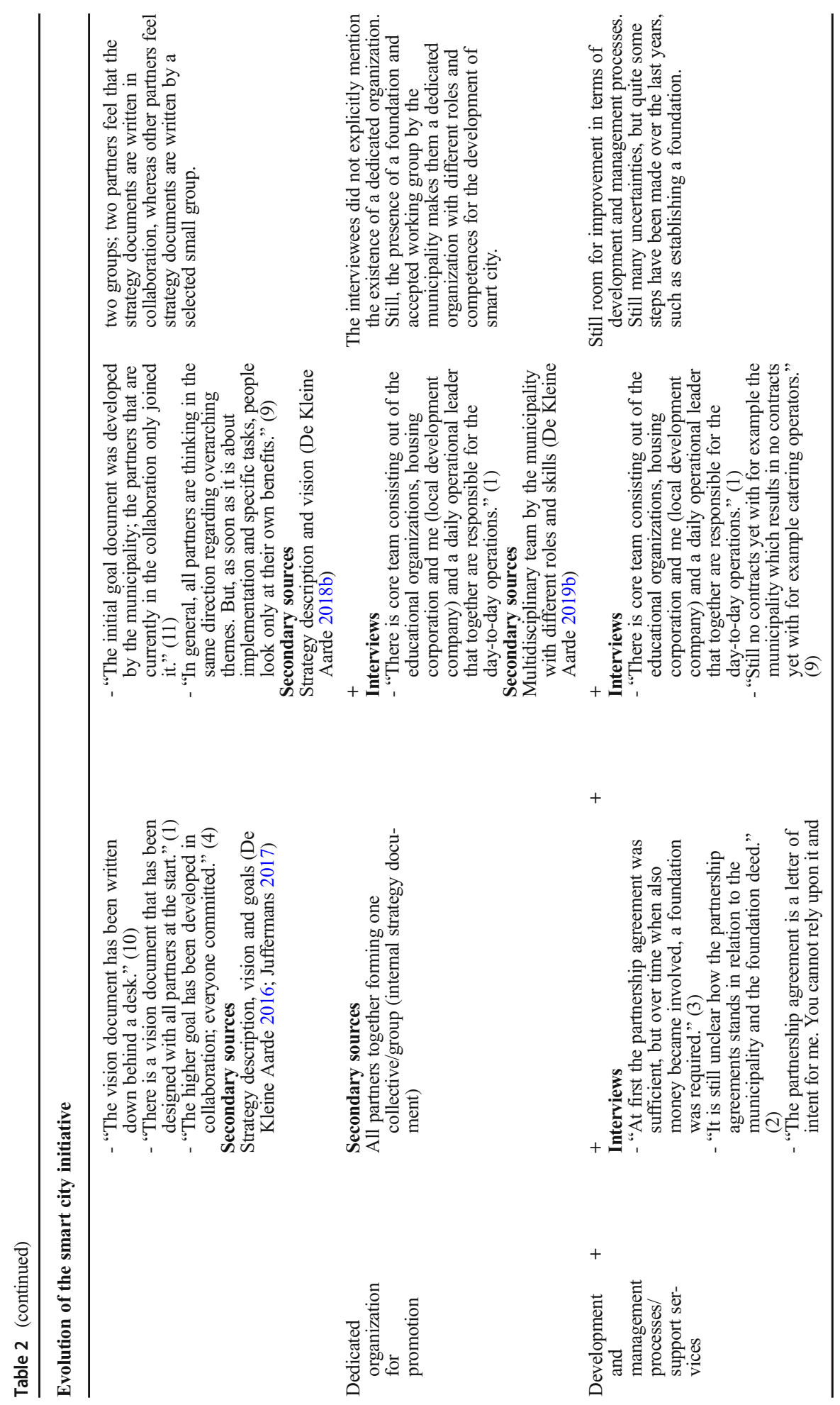




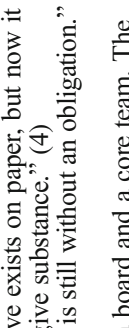

$\stackrel{\overbrace{}}{\rightleftarrows}$

\&. $: 0$

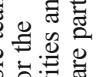

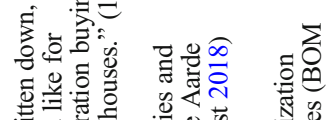

.

웡

구을

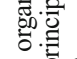

풀

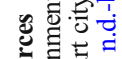

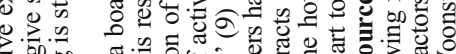

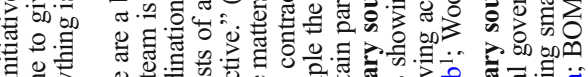

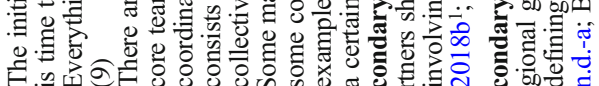

5.

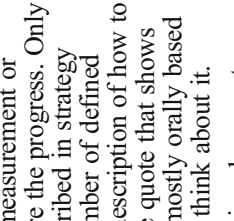

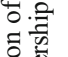

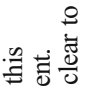

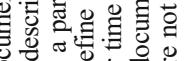
更

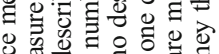

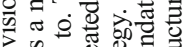

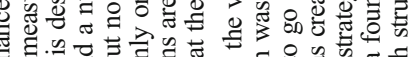

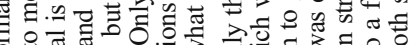

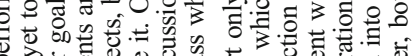

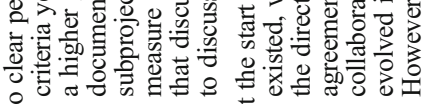
之 荌
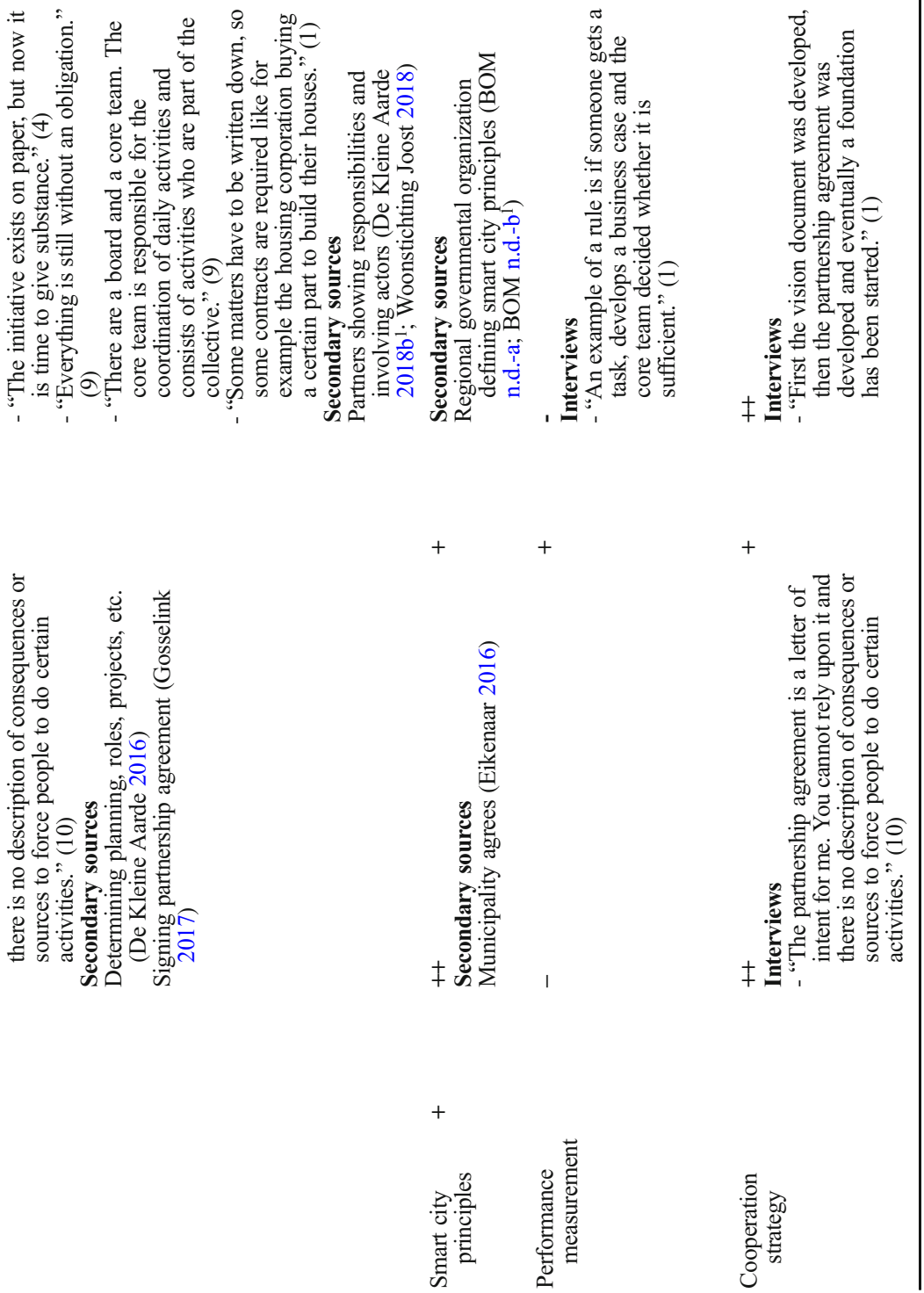


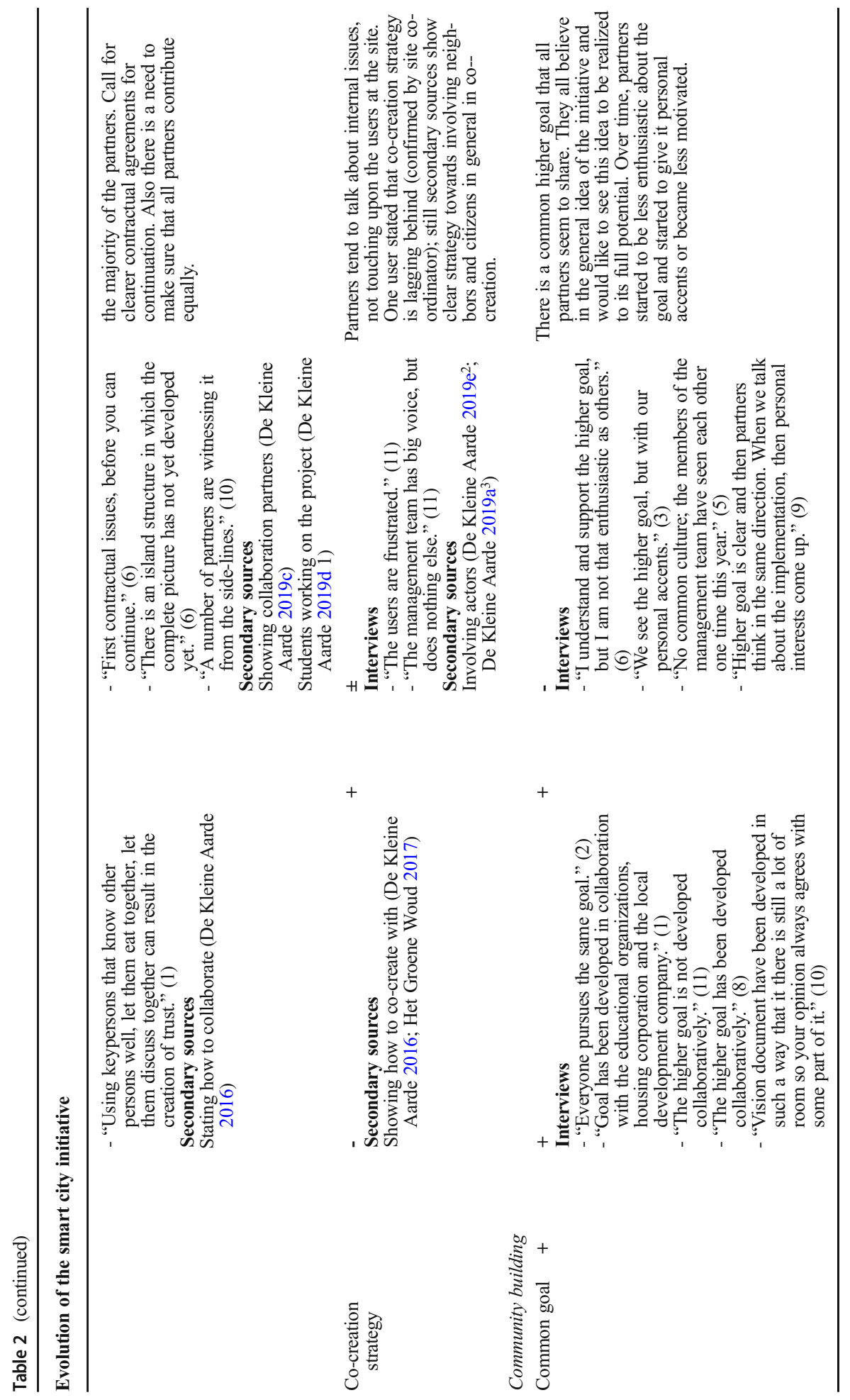




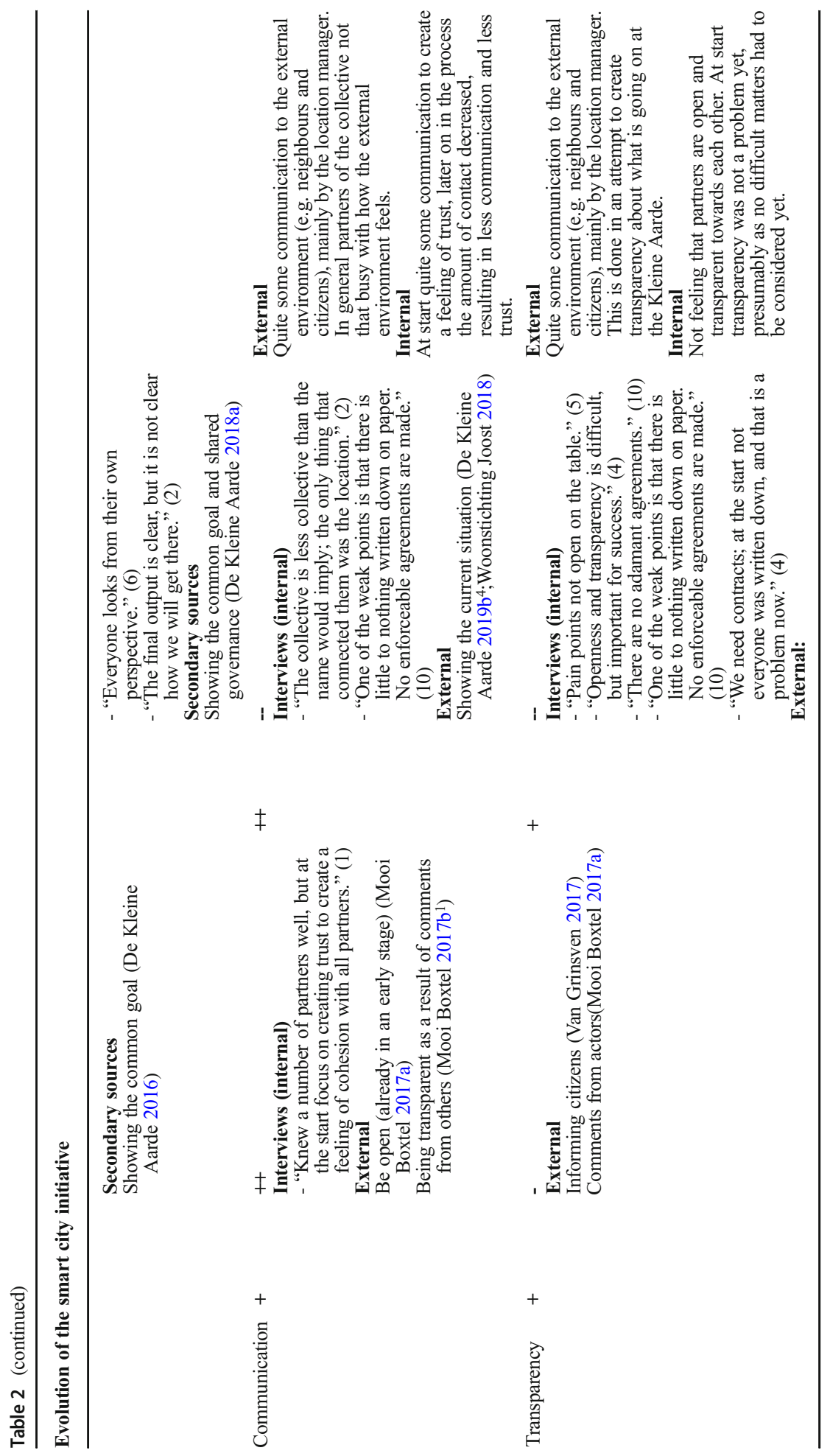




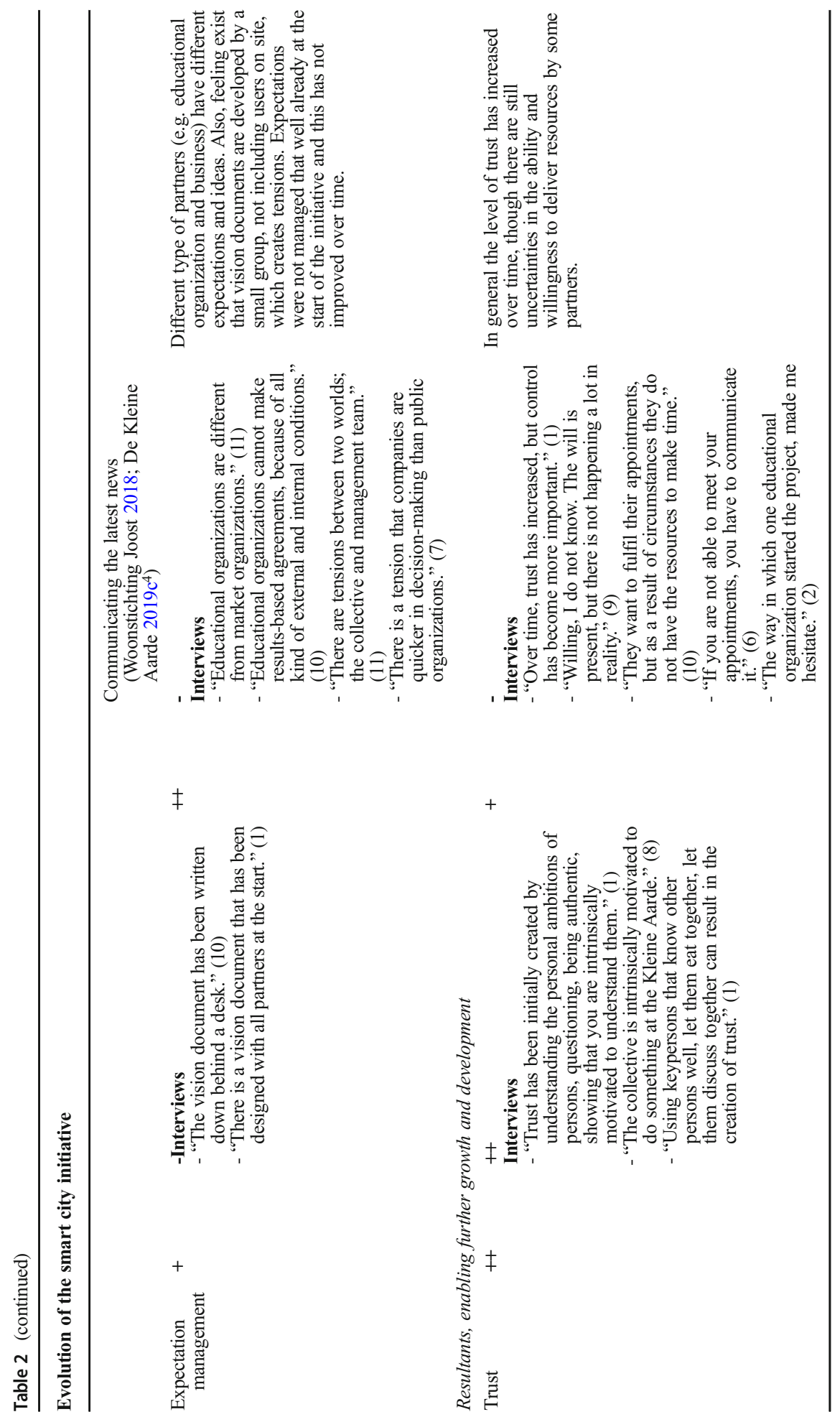




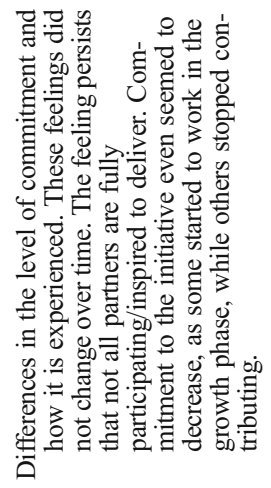

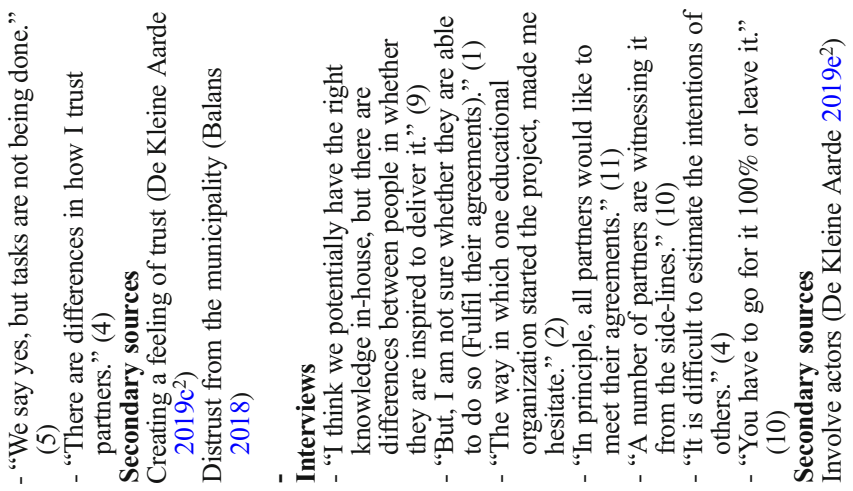

$+$

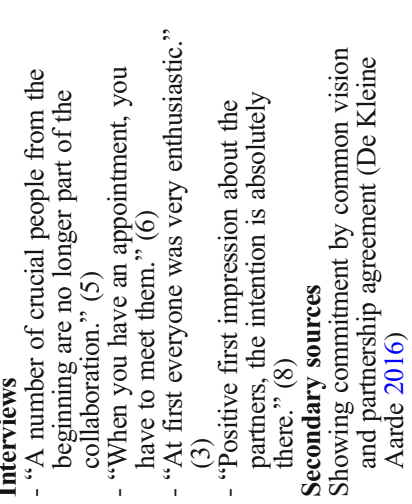

葛 
to participate in the formulation ("The higher goal is not developed collaboratively." (11)). Although a common goal was clearly present, it was not unanimously supported by the group of participants.

Another factor influencing the effective governance of smart city ecosystems is communication. Our evidence suggests that communication received quite some attention in this phase to create a sense of community among ecosystem partners and the external environment, as well as to initiate the collaboration. Interviewee 1 notes that this was to establish trust: "[I] knew a number of partners well, but at the start [there was a] focus on creating trust to create a feeling of cohesion with all partners". In this particular phase, communication is therefore an enabling element.

Trust is a governance element that is influenced by some of the other dimensions that have been described above. The literature shows that trust can serve as a very strong enabler of ecosystem effectiveness as it stimulates lasting, mutually beneficial relationships among partners (e.g., Sandulli et al. 2017; Cobben and Roijakkers 2019). In some cases, trust can even serve as an effective alternative to control-based governance structures to align partners in working towards common ecosystem goals. The establishment of trust has received significant attention in initiation ("Using key persons that know other persons well, let them eat together, let them discuss together can result in the creation of trust." (1)). Ecosystem partners feel that "The collective is intrinsically motivated to do something at the "Kleine Aarde" (8).

Finally, studies show that commitment is an important dimension determining the governance of ecosystems for smart cities (e.g., Kale and Singh, 2009, Sandulli et al. 2017). In the initiation phase, ecosystem partners felt motivated and enthusiastic ("Positive first impression about the partners, the intention is absolutely there." (8)). Yet there were some important people who chose to leave the ecosystem. Secondary data shows that commitment was also documented in a common vision and partnership agreement, though some partners saw these documents as letters of intent rather than agreements set in stone.

Although we found evidence of several governance factors from our theoretical model, several factors from our framework were not (yet) identified in the initiation phase. A dedicated organization for promotion, for example, was not found in the initiation phase. This factor is likely to receive attention only in the growth phase, which is consistent with the innovation ecosystem literature on evolution and ecosystem phases. Related to the lack of a dedicated organization for promotion is the lack of a co-creation strategy; in the first phase the focus was on internal cooperation rather than co-creation. In a similar vein, performance management was not a focus area of the ecosystem's governance during initiation as value appropriation is likely to occur at a later stage. Development and management processes were not fully present, though some attention was paid by the ecosystem partners to a first definition of roles, responsibilities, and actor involvement. Despite the intention to have these processes in place, interviewees note that interactions occur without an obligation. As such, and in relation to a lack of well-established roles, responsibilities, etc., we also did not find any evidence of the presence of expectation management. Partners have different expectations of each other and the ecosystem depending on whether they are a public organization, an educational institution or a company. At the time, little effort was devoted to clarify these backgrounds and reach a common understanding. Last, internal transparency was not specifically mentioned. While quite a few documents (e.g. 
documents explaining what the ecosystem entails and sets out to achieve) within our database of secondary sources point at the importance of external transparency and openness, within "De Kleine Aarde" smart city ecosystem experiment, no interviewee mentioned activities to establish internal transparency.

\section{Growth phase}

When it comes to the governance factor of leadership, interviewees note that clear leadership during the growth phase was still not present. They consider this an inhibiting factor: "A dedicated (project) leader is required for success" (10). While there are parties within the ecosystem that could be considered leaders (i.e. the coordinating, facilitating partner, the chairman of the board of the foundation, or the location manager), they are not viewed as such by ecosystem partners.

In terms of strategy, some partners feel committed to the ecosystem's strategy while others do not, depending on the extent to which they were able to contribute to the formulation of a common strategy in the initiation phase. In the growth phase, strategy can be expected to go beyond the design of the smart city initiative and move towards implementation aspects. Partners note that: "In general, all partners are thinking in the same direction regarding overarching themes. But, as soon as it is about implementation and specific tasks, people look only at their own benefits" (9). As such, the status of this particular factor is inhibiting ecosystem effectiveness during growth.

As soon as internal relations are established, a dedicated organization for promotion that can manage the ecosystem vis-à-vis its external environment becomes important. In our case, we find a core team that consists of a formal project leader, a quartermaster, a firm representative, and an educational organization representative. The core team is endowed with the skills and the authority to develop the smart city, and it is acknowledged as such by outside parties. Interviewee 1 points out: "There is core team consisting of the educational organizations, housing corporation, me (local development company), and a daily operational leader that together are responsible for the day-to-day operations." The fact that this team with the necessary skills and responsibilities is in place, and the team is recognized as the dedicated organization by the municipality, points at this dimension constituting an enabling factor of ecosystem effectiveness.

Similar to the initiation phase, development and management processes received some attention in the growth phase. Secondary data shows that roles, responsibilities, and actor involvement have been defined. Although there had been a partnership agreement which was signed by all parties, after a while it became clear that this partnership agreement was not suitable to sustain the growth of the initiative. A number of organizations that signed the partnership agreement were not allowed to take financial risks nor were they allowed to handle external cash flows. At the end of 2017, a foundation was established to solve these issues. This was seen by all as the start of phase II, the growth phase. The foundation is governed by a board, consisting of a chairman, secretary, and a member. We find that the establishment of the foundation has clarified roles and responsibilities to some extent: "At first the partnership agreement was sufficient, but over time when also money became involved, a foundation was required" (3). While highly improved upon over time, this factor still needs further development and cannot be considered an enabling factor yet: "Everything is still without an obligation" (9). 
Comparable to the initiation phase, also in the growth phase, "De Kleine Aarde" partners have not yet established any formal (output) performance criteria to measure the partners' contributions and progress towards the strategic goals of the ecosystem. For now, performance is measured based on input control as interviewee 1 exemplifies: "An example of a rule is if someone gets a task, develops a business case and the core team decided whether it is sufficient". A more elaborate performance measurement system based on input, process, and output control and corresponding key performance indicators would turn this factor into an enabling factor for "De Kleine Aarde". Such a system would allow for forging more focused, effective actions towards strategic goals.

Evidence (both interview quotes and secondary data) with respect to the cooperation strategy points at the positive evolution of this governance factor during the growth of the smart city. While there are still points for improvement, the strategy with respect to partnering is shown to gradually contribute to governance, as partners report that they are more aware than they were before of what is expected from them: "First the vision document was developed, then the partnership agreement was developed and eventually a foundation has been started" (1). Still, some interviewees note that quite some steps have to be made to develop a cooperation strategy that fully connects all partners. They point to fragmentation between several isolated (groups of) partners. Whereas progress has been made in the development of the cooperation strategy, the co-creation strategy has only just been started. While efforts have been made to actively involve citizens (see secondary data sources in Table 2), these activities do not seem to have the expected effects yet: "The users are frustrated" (11).

The next factor refers to the presence of common goals. A common higherlevel goal was formulated in phase I ("The higher goal has been developed collaboratively." (8)). However, some partners' commitment to this goal seems to have dwindled over time ("I understand and support the higher goal, but I am not that enthusiastic as others." (6)). Furthermore, the establishment of commonalities is still in need of further development: "[There is] no common culture; the members of the management team have seen each other on a single occasion this year." (5). This may be related to one of the previously described factors where we found that the implementation of strategy is still lacking and key output indicators have not yet been formulated. Thus, the lack of common goals currently works as an inhibiting factor.

Whereas communication received quite some attention in the initiation phase, and could be seen as an enabling factor, things have changed for the worse during the growth phase. Over time, going from phase I to phase II, communication has received less attention, resulting in a decrease in trust among partners. As one interviewee notes: "The collective is less collective than the name would imply; the only thing that connected them was the location" (2). As such, the neglect of this factor inhibits ecosystem development.

Another factor in our theoretical framework is transparency. Internal transparency among partners is in need of improvement. Whereas in the initiation phase the presence of internal transparency was not specifically recognized by interviewees, this started to concern interviewees only during the growth phase ("Pain points [are] not open on the table." (5)). This is possibly related to partners lacking a sense of common goals in the 
short run. While transparency currently functions as an inhibiting factor, partners acknowledge the need for more openness to increase the likelihood of success of the ecosystem: "Openness and transparency is difficult, but important for success." (4).

Expectation management seems to have been neglected within "De Kleine Aarde", not only in the initiation phase, but also in the growth phase. Over time, little effort was made to clarify backgrounds and reach a common understanding of where each partner is coming from, thus managing expectations with respect to each partner's behavior within the ecosystem. Interviewee 7 points at the tensions among ecosystem partners resulting from mismatched expectations: "There is a tension that companies are quicker in decision-making than public organizations."

While the establishment of trust has received significant attention in phase I ("Using key persons that know other persons well, let them eat together, let them discuss together can result in the creation of trust." (1)), the lack of clear leadership, the lack of short-term, attainable goals, the lack of understanding for different partners' organizational backgrounds, etc. in phase II may have resulted in halting trust development. Interviewee 4 summarizes this as "there are differences in how I trust partners." Interviewee 2 adds: "The way in which one educational organization started the project, made me hesitate."

Similar to trust, commitment has also decreased during the evolution of "De Kleine Aarde", thus starting to act as an inhibiting factor. Interviewee 3 states: "At first everyone was very enthusiastic". Interviewee 9 mentions the following regarding a decreasing commitment in phase II: "I think we potentially have the right knowledge in-house, but there are differences between people in whether they are inspired to deliver it."

\section{Overarching insights}

We found that during the evolution of the smart city the focus shifted from certain governance elements to others. Furthermore, we found that the character of the attention that is required by some governance elements needs adaptation over time. For example, although there is a continuous need for leadership throughout all phases of evolution, our case study results demonstrate that a different kind of leadership is required in each phase. In the initiation phase, the need for leadership takes the form of a need for relationship building, while in the growth phase a more controlling leadership is required. This is related to the increasing needs of setting, advocating, and checking performance measures as the ecosystem grows.

The evolution of "De Kleine Aarde" demonstrated that overlooking a certain governance element in the initiation phase, or neglecting an element in the growth phase, has negative consequences for the success of the smart city as a whole. This is so because, governance elements are interdependent. The neglect of one element can reverberate throughout the ecosystem, and may potentially lead to its demise. For example, a clear and shared strategy (devised of in the initiation phase) is crucial for the development of performance measurement and management processes (to be developed in the growth phase). Moreover, "De Kleine Aarde" showed that in order to establish a strategy that is widely accepted during the initiation phase, it is important that there are governance elements in place that generate the trust and commitment of partners. 


\section{Discussion and conclusion}

\section{Summary of results}

This study contributes to the literature by investigating how governance elements are used within a smart city ecosystem. We have integrated different literatures to study a rich, single case of a smart city initiative. Our findings and their theoretical implications are twofold. First, we find that across different phases of ecosystem evolution, different sets of governance elements are used to effectuate development of the smart city (Fig. 3), and we thus identify the governance elements that go together in each phase of evolution. Second, we contribute to the literature by illustrating the interconnectedness of governance elements. That is, our results indicate that governance elements interact, influencing each other's effectiveness in stimulating smart city ecosystem development. In other words, we propose that having the set of governance elements in place in its corresponding phase of evolution goes above and beyond having just some of the elements that are to be part of said set in place.

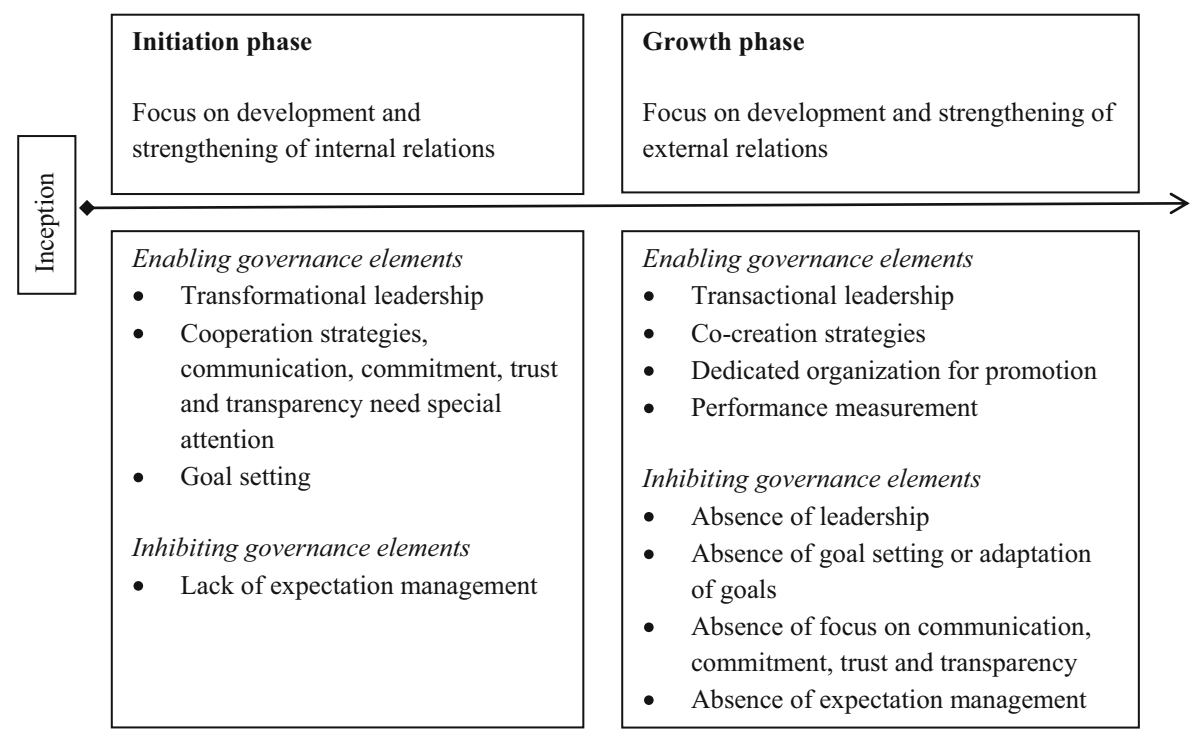

Essential in both phases

- Setting common goals has to start in the initiation phase and needs to continue during the growth phase. There is a tendency to neglect goal setting in the growth phase.

- Communication, commitment, trust and transparency need continued attention during growth phase

- Smart city principles

- Establishing a joint overall strategy

- Development and management processes

Fig. 3 Enablers and inhibitors in each phase 
Figure 3 presents our findings regarding two different sets of governance elements across phases of evolution. In the initiation phase the focus is on strengthening internal relations. In the growth phase governance elements that are used aim at developing external relations with, for example, co-creation partners.

\section{Discussion and theoretical contribution}

An important result of our study is that the exact content of governance elements can change over time as the smart city evolves. This finding was especially prominent with respect to the factor leadership. We found that in the initial stage, leadership should be more informal and transformational in nature (e.g. the leader(s) should be coordinating and facilitating others, rather than controlling and reviewing others), while in the growth phase the role of leadership changes. Then, leadership of a rather formal and control-based nature is essential for success. We also found that other governance factors, such as cooperation strategies, communication, commitment, trust and transparency need special attention during the initiation phase. This pattern of results is consistent with what is known from the leadership literature. In the initiation phase, leadership of a transformational nature may be conducive to success. The leader has the role of inspirator and stimulator (e.g. Rosing et al. 2011). To sustain the success of the system during the phase of growth, more transactional leadership (exchangebased leadership with reward based on performance measurement; e.g. Rosing et al. 2011) needs to be exerted. A possible reason for this change in the governance element over the evolution of the system may be that in an early phase more creativity and innovation is required to start up and design the smart city, whilst during the growth phase governance becomes more and more complex, as additional partners join and want to create and capture benefits for themselves. Interestingly, this finding contradicts findings of other smart city studies, which claim that initiators should exercise strong leadership, via goalsetting and performance measurement, from the start (Paskaleva 2009; Bolici and Mora 2015). Yet these studies also pose that leadership at the start is needed mostly to promote the initiative and to convince parties to collaborate (Paskaleva 2009; Bolici and Mora 2015), which corroborates with our findings. Transformational leadership is likely to be most suited for activities such as strengthening internal relationships. In contrast, we see in our study in the growth phase a set of governance elements that is linked to more transactional leadership, such as cocreation strategies (where partners intend to create and capture value), dedicated (formal) organizations for promotion of the smart city, and a large role for performance measurement activities. Nonetheless, governance elements that were essential during the initiation should not be abandoned after the initial stage, instead these strategies should be nurtured as the smart city continues to grow.

The implications of these findings provide a new perspective on studies that are critical on smart city initiatives. Calzada and Cobo (2015) question the idealistic smart city concept, which assumes that actors in smart cities collectively develop an economically prosperous and socially justified ecosystem without much need for clear leadership (Jacobs 1970; Welter 2003), and call for top-down approaches instead. Our 
case study's results rather take the midst between these extremes: Top-down leadership is not required (or may even be counterproductive) during the initiation, but that is not to say that there should be no leadership. Rather, we propose that different leadership is needed in the initiation phase (transformational) and the growth phase (transactional), and that these elements should be accompanied by further, related governance elements.

Cooperation strategies and co-creation strategies are also important in the growth phase to develop the external relations that are crucial for the success of an ecosystem. We find that setting common goals has to continue during the growth phase. Our case study illustrated that there is a tendency to set goals in the initiation phase, however, over time these goals tend to be forgotten or to become outdated. For successful ecosystem development it is required that partners continue to set and adapt goals when an ecosystem starts to grow (Usman et al. 2018). Hence, it is important to have both short-term and long-term goals, to warrant that ecosystem partners remain focused and motivated during the growth phase of the smart city. This finding is in line with innovation system studies that argue that dissimilar partners need to be united through common goals (e.g., Pullen et al. 2012; Caniëls and Romijn 2008a; Robards et al. 2011).

Although communication, commitment, trust and transparency may receive quite some attention in the initiation phase, our case study shows that these governance elements tend to be neglected to some extent in the growth phase. In our case study this turned out to be hampering the growth of the smart city initiative. Extensive research in related fields has shown that in the close interaction between actors tacit and informal knowledge is exchanged, which is essential for building relationships and generating trust (Hoogma et al. 2002). Communication also helps to reduce uncertainty and complexity that are inherent in radical innovation projects such as smart city initiatives (Hollands 2008; Caniëls and Romijn 2008a, 2008b; Mora et al. 2017).

We found that smart city principles are crucial for the success of an ecosystem, independent of the phase. It is important that the local government is supported by other governments (e.g. regional, national or international governments) by a stimulating regulatory environment for smart city planning and development. Relatedly, results show that in both the initiation and the growth phase a clear strategy should be present which is developed in collaboration with all partners involved. Only when a strategy is widely supported and goes beyond simple intentions, partners will feel committed and willing to contribute. Our study nuances the findings by Bolici and Mora (2015) that show that smart city strategy has to be aligned with the strategic framework of the city. Specifically, we find that development and management processes are important to provide ecosystem partners the guidance and structures that they need to move beyond simple intentions into actual solutions in both the initiation and growth phase.

Only after the strategy is clear, formal (output) criteria can be set to measure each partner's contribution and progress towards strategic ecosystem goals and performance measurement is possible. Furthermore, our study demonstrates that a dedicated organization for promotion can only function after internal relationships are established. Hence, we find that only in the growth phase there is a role for this governance element. 


\section{Implications for policy and practice}

We can derive two policy implications from our study, both related to our findings that in each phase of development, different elements need special attention. That is, apart from some factors that need continuous attention (e.g. trust and commitment), the initiation phase and the growth phase will each require a rather unique approach. First, policy makers and leaders of smart cities should direct financial stimuli to different governance elements over time. One example of these changing accents is the need for policy makers and leaders to re-evaluate the smart city goals moving from one phase to the other. Another is that during the phase of growth, financial stimuli should help the ecosystem to act upon, for example, performance measurement. Second, we recommend policy makers to consider that (individuals from) different types of organizations (private and public) could take the lead along the development continuum. In the initiation phase, potentially any partner with legitimacy in the eye of the beholders (i.e. the other ecosystem partners) could take the lead. Our case study illustrates how none of the individuals in a leadership role during initiation of "De Kleine Aarde" were actually perceived of as the transformational leader the other partners were looking for. During growth, we have seen the need for transactional leadership, which means that the partner who is in the lead should somehow have the authority over other partners to measure performance, and to reward or penalize accordingly. Policy makers and leaders should consider to whom leadership should be attributed in each phase of development.

\section{Limitations and direction for future research}

This study comes with three limitations that may inform future research. First, several limitations are connected to the research design and sample. The current study is based on single case study data. Although this allowed us to trace governance in the smart city initiative as it unfolded in-depth, it limits the generalizability of our findings. Future studies should seek to examine governance across additional smart city ecosystems. Furthermore, our case study data is limited to two phases of ecosystem evolution, i.e. initiation and growth. The case that was studied did not yet exhibit any characteristics of an ecosystem in the phase of maturity. It would be interesting to collect data on cases that are in a maturity phase of their existence, not in the least because Lee et al. (2014) point to an evolving role of public and private actors in smart cities over time, with private actors holding a more central position only in mature phases, and public actors having a focal role in earlier phases of development. Additionally, it may be relevant to include cases of smart cities that cease to exist or do not reach certain phases of evolution (failure cases), in order to get a better perspective on inhibiting governance elements in particular.

Second, our findings imply that different governance elements may interact. There may be trade-offs, substitution effects, and/or interaction effects. Ecosystem literature does not focus on understanding the interaction between dimensions, let alone the differences in importance for phases of evolution. Archival research or survey research may be able to test such relationships between variables.

Third, our study demonstrated that the lack of expectation management and alignment of expectations of different actors within the initiative was perceived as an inhibiting factor throughout both phases. Future research could focus on ways in which 
different expectations from various actors can be aligned. What processes are conducive for aligning expectations? In this respect, it may be worthwhile to build on literature about Strategic Niche Management (e.g., Caniëls and Romijn 2008a), which is an approach designed to facilitate the introduction and diffusion of radically new sustainable technologies through societal experiments. Convergence and alignment of expectations of participating actors is one of the key niche processes that receives attention in Strategic Niche Management (Caniëls and Romijn 2008b).

\section{Conclusion}

This research shows the importance of governance for smart city initiatives. We present an overview of how governance elements are used in different phases of evolution and how they influence smart city ecosystem development. Certain governance factors such as the establishment of a common goal, a joint overall strategy, and an internal cooperation strategy are likely to be beneficial to ecosystem effectiveness in the initiation phase. As the ecosystem grows and starts to position itself vis-à-vis its environment other factors may need more governance attention, e.g. the establishment of a dedicated organization for promotion and a co-creation strategy. Factors such as performance measurement will be more likely to influence ecosystem effectiveness in maturity where value appropriation becomes more prevalent. Leadership, effective processes, smart city principles, communication, transparency, expectation management, trust, and commitment are important governance elements throughout an ecosystem's evolution. In addition, we found that these dimensions influence each other's effectiveness in reaching smart city development goals. Based on our findings, we conclude that governance elements are used differently during the evolution of a small city ecosystem and some governance elements interact.

\section{Appendix A}

Table 3 - Overview of interviewees

\begin{tabular}{lll}
\hline Interviewee & Role & Organization \\
\hline 1 & Senior manager & Governmental organization \\
2 & Director & Governmental organization \\
3 & Senior manager & Governmental organization \\
4 & Director & Company \\
5 & Director & Company \\
6 & Director & Educational institution \\
7 & Senior manager & Educational institution \\
8 & Director & Educational institution \\
9 & Middle manager & Governmental organization \\
10 & Senior manager & Educational institution \\
11 & Middle manager & Company \\
\hline
\end{tabular}




\section{Appendix B}

Table 4 - Overview of factors and corresponding codes

\begin{tabular}{|c|c|}
\hline Factor & Code(s) \\
\hline Leadership & $\begin{array}{l}\text { Coordinating role } \\
\text { Leader } \\
\text { Visionary thinking } \\
\text { Taking the lead } \\
\text { Facilitator } \\
\text { Coordinator }\end{array}$ \\
\hline Strategy & $\begin{array}{l}\text { Vision document } \\
\text { Goals } \\
\text { Strategy description } \\
\text { Vision } \\
\text { Strategy implementation } \\
\text { Same direction }\end{array}$ \\
\hline Dedicated organization for promotion & $\begin{array}{l}\text { Steering group } \\
\text { Board } \\
\text { Core team } \\
\text { Working group } \\
\text { Promoting }\end{array}$ \\
\hline Development and management processes & $\begin{array}{l}\text { Roles } \\
\text { Agreement } \\
\text { Planning } \\
\text { Projects } \\
\text { Contracts } \\
\text { Operations }\end{array}$ \\
\hline Smart city principles & $\begin{array}{l}\text { Agreements } \\
\text { Vision } \\
\text { Mission }\end{array}$ \\
\hline Performance measurement & $\begin{array}{l}\text { Metrics } \\
\text { Criteria } \\
\text { Objectives }\end{array}$ \\
\hline Cooperation strategy & $\begin{array}{l}\text { Partnership agreement } \\
\text { Letter of intent } \\
\text { Common activities } \\
\text { Team feeling } \\
\text { Collaboration details }\end{array}$ \\
\hline Co-creation strategy & $\begin{array}{l}\text { Participation } \\
\text { Inclusion } \\
\text { Involvement }\end{array}$ \\
\hline Common goal & $\begin{array}{l}\text { Same goal } \\
\text { Higher goal } \\
\text { Vision document } \\
\text { Common culture }\end{array}$ \\
\hline Communication & $\begin{array}{l}\text { Openness } \\
\text { Current situation } \\
\text { Connections } \\
\text { Meetings } \\
\text { Mail/phone }\end{array}$ \\
\hline Transparency & $\begin{array}{l}\text { Openness } \\
\text { Sharing documents } \\
\text { Sharing information }\end{array}$ \\
\hline
\end{tabular}


Table 4 (continued)

\begin{tabular}{ll} 
Factor & Code(s) \\
\hline & Distance leader and actors \\
Expectation management & Social media \\
& Openness \\
Trust & Communication \\
& Transparency \\
& Letter of intent \\
& Understanding \\
Commitment & Motivation \\
& Shared activities \\
& Willingness \\
& Honesty \\
& Resources \\
& Membership \\
& Intentions \\
\end{tabular}

Open Access This article is licensed under a Creative Commons Attribution 4.0 International License, which permits use, sharing, adaptation, distribution and reproduction in any medium or format, as long as you give appropriate credit to the original author(s) and the source, provide a link to the Creative Commons licence, and indicate if changes were made. The images or other third party material in this article are included in the article's Creative Commons licence, unless indicated otherwise in a credit line to the material. If material is not included in the article's Creative Commons licence and your intended use is not permitted by statutory regulation or exceeds the permitted use, you will need to obtain permission directly from the copyright holder. To view a copy of this licence, visit http://creativecommons.org/licenses/by/4.0/.

\section{References}

Albino, V., Berardi, U., \& Dangelico, R. M. (2015). Smart cities: Definitions, dimensions, and performance. Journal of Urban Technology, 22(1), 3-21.

Angelidou, M. (2014). Smart city policies: A spatial approach. Cities, 41, S3-S11.

Angelidou, M. (2017). The role of smart city characteristics in the plans of fifteen cities. Journal of Urban Technology, 24(4), 3-28.

Ardito, L., Ferraris, A., Petruzzelli, A. M., Bresciani, S., \& Del Giudice, M. (2019). The role of universities in the knowledge management of smart city projects. Technological Forecasting and Social Change, 142, $312-321$.

Balans (2018). Innen achterstallige huuropbrengst De Kleine Aarde [PDF]. Retrieved from: https://www. balansboxtel.nl/attachments/article/283/2018-10-30\%20BALANS\%20Motie\%20Innen\%20 achterstallige\%20huuropbrengst $\% 20 \mathrm{De} \% 20 \mathrm{Kleine} \% 20$ Aarde.pdf.

Bolici, R., \& Mora, L. (2015). Urban regeneration in the digital era: How to develop Smart City strategies in large European cities. TECHNE: Journal of Technology for Architecture and Environment, 5(2), 110-119.

BOM (n.d.-a) 'Wij creeren meerwaarde door data van verschillende partijen te combineren. Retrieved from: https://prestaties.bom.nl/klantervaringen/a1371_\%E2\%80\%98Wij-creeren-meerwaarde-door-data-vanverschillende-partijen-te-combineren $\% \mathrm{E} 2 \% 80 \% \overline{9} 9$.

BOM (n.d.-b) 1. Smart City: Data-ownership \& Ethiek. Retrieved from: https://www.bom.nl/overbom/events/smart-city-data-ownership-ethiek.

Brenner, T., \& Schlump, C. (2011). Policy measures and their effects in the different phases of the cluster life cycle. Regional Studies, 45(10), 1363-1386. 
Calzada, I., \& Cobo, C. (2015). Unplugging: Deconstructing the Smart City. Journal of Urban Technology, $22(1), 23-43$.

Caniëls, M. C. J., \& Romijn, H. A. (2008a). Actor networks in strategic niche management: Insights from social network theory. Futures, 40(7), 613-629.

Caniëls, M. C. J., \& Romijn, H. A. (2008b). Strategic niche management: Towards a policy tool for sustainable development. Technology Analysis \& Strategic Management, 20(2), 245-266.

Cobben, D., \& Roijakkers, N. (2019). The dynamics of trust and control in innovation ecosystems. International Journal of Innovation, 7(1), 1-25.

Deakin, M. (2014). Smart cities: The state-of-the-art and governance challenge. Triple Helix, 1(1), 7.

De Kleine Aarde (2016). De Kleine Aarde naar een frisse start. Boxtel: the Netherlands: Heijmans, Helicon, Maris Projects, Sint Lucas, Summa College, Waterschap de Dommel, Woonstichting Sint Joseph, Rabobank, and BOM.

De Kleine Aarde (2018a). Samenwerking. Retrieved from: https://dekleineaarde.nl/samenwerking.

De Kleine Aarde (2018b) 1. Energie en de kleine aarde. Retrieved from: https://dekleineaarde. $\mathrm{nl} /$ nieuws/energie-en-de-kleine-aarde.

De Kleine Aarde (2019a). Nieuws. Retrieved from: https://dekleineaarde.nl/.

De Kleine Aarde (2019b) 1. Studenten Summa bouwen nieuwe bijenhal. Retrieved from: https://dekleineaarde.nl/nieuws/studenten-summa-bouwen-nieuwe-bijenhal.

De Kleine Aarde (2019c)2. Zomerborrel met barbecue De Kleine Aarde druk bezocht. Retrieved from: https://dekleineaarde.nl/nieuws/zomerborrel-met-barbecue.

De Kleine Aarde (2019d) 3. Meedenken over duurzaam en comfortabel leven op De Kleine Aarde? Retrieved from: https://dekleineaarde.nl/nieuws/meedenken-over-duurzaam-en-comfortabel-leven-op-de-kleineaarde.

De Kleine Aarde (2019e) 4. Energie en De Kleine Aarde. Retrieved from: https://dekleineaarde. $\mathrm{nl} /$ nieuws/energie-en-de-kleine-aarde.

Drimble (n.d.). Stichting De Kleine Aarde. Retrieved from: https://drimble.nl/bedrijf/boxtel/k70370338 /stichting-de-kleine-aarde.html.

Eikenaar, H. (2016). Boxtelse raad: collectief mag de Kleine Aarde herontwikkelen. Retrieved from: https://www.bd.nl/boxtel/boxtelse-raad-collectief-mag-de-kleine-aarde-herontwikkelen ae15baaa/.

Eisenhardt, K. M. (1989). Building theories from case study research. The Academy of Management Review, 14(4), 532-550. https://doi.org/10.2307/258557.

Eisenhardt, K. M., \& Graebner, M. E. (2007). Theory building from cases: Opportunities and challenges. The Academy of Management Journal, 50(1), 25-32.

Eremia, M., Toma, L., \& Mihai, S. (2017). The Smart City concept in the 21 st century. Procedia Engineering, $181,12-19$.

Fernandez-Anez, V., Fernandez-Guell, J. M., \& Giffinger, R. (2018). Smart City implementation and discourses: An integrated conceptual model. The Case of Vienna. Cities, 78, 4-16.

Ferraris, A., Belyaeva, Z., \& Bresciani, S. (2018). The role of universities in the Smart City innovation: Multistakeholder integration and engagement perspectives. Journal of Business Research.

Ferraris, A., Erhardt, N., \& Bresciani, S. (2019). Ambidextrous work in smart city project alliances: Unpacking the role of human resource management systems. The International Journal of Human Resource Management, 30(4), 680-701.

Garud, R., Berends, H., \& Tuertscher, P. (2017). Qualitative approaches for studying innovation as process. In R. Mir \& S. Jain (Eds.), The Routledge companion to qualitative research in organization studies. London: Routledge.

Gibbert, M., Ruigrok, W., \& Wicki, B. (2008). What passes a rigorous case study? Strategic Management Journal, 29(13), 1465-1474.

Girardi, P., \& Temporelli, A. (2017). Smartainability: A methodology for assessing the sustainability of the smart city. Energy Procedia, 111, 810-816.

Gosselink, P. (2017). 't COLLECTIEF DE KLEINE AARDE BOXTEL aan de gang. Retrieved from: https://www.linkedin.com/pulse/collectief-de-kleine-aarde-boxtel-aan-gang-paulgosselink/?originalSubdomain=n.

Het Groene Woud (2017). Meld je aan voor het Klene Aarde Netwerk in Boxtel. Retrieved from: https://www. hetgroenewoud.com/actueel/nieuws/meld-je-aan-voor-het-kleine-aarde-netwerk-in-boxtel/656.

Hollands, R. G. (2008). Will the real smart city please stand up? City, 12(3), 303-320.

Hoogma, R., Kemp, R., Schot, J., \& Truffer, B. (2002). Experimenting for sustainable transport. The approach of strategic niche management. London: Spon Press. 
Isenberg, D. (2011). The entrepreneurship ecosystem strategy as a new paradigm for economic policy: Principles for cultivating entrepreneurship. Presentation at the Institute of International and European Affairs, 1-13.

Jacobs, J. (1970). The economy of cities. New York: Random House.

Jansen, K. (2016). Technotrend in slimme stad verruild voor menselijke maat. Retrieved January 10, 2019 from: https://platformoverheid.nl/artikel/techno-trend-in-slimme-stad-verruild-voor-menselijke-maat/.

Juffermans, J. (2017). Fieldlabs Kleine Aarde gaan Brabant verbazen [PDF File]. Retrieved from: http://www. janjuffermans.nl/activiteiten/fieldlabskleineaarde.pdf.

Kale, P., Singh, H., \& Raman, A. P. (2009). Don't integrate your acquisitions, partner with them. Harvard business review, 87(12), 109-115.

King, S., \& Cotterill, S. (2007). Transformational government? The role of information technology in delivering citizen-centric local public services. Local Government Studies, 33(3), 333-354.

Komninos, N., \& Mora, L. (2018). Exploring the big picture of Smart City research. Science Regionali, 17(1).

Kumar, H., Singh, M.K., Gupta, M.P., \& Madaan, J. (2018). Moving towards smart cities: Solutions that lead to the Smart City transformation framework. Technological Forecasting and Social Change.

Lam, W. (2005). Barriers to e-government integration. Journal of Enterprise Information Management, 18(5), $511-530$.

Lee, J. H., Hancock, M. G., \& Hu, M. (2014). Towards an effective framework for building smart cities: Lessons from Seoul and San Francisco. Technological Forecasting and Social Change, 89, 80-99.

Leroi-Werelds, S., Pop, O., \& Roijakkers, N. (2017). Understanding value creation in alliance ecosystems: Insights from marketing. In das, T.K. (ed), City University of New York: New York.

Letaifa, S. B. (2015). How to strategize SMART cities: Revealing the SMART model. Journal of Business Research, 68(7), 1414-1419.

Leydesdorff, L., \& Deakin, M. (2011). The triple helix of smart cities: A neo-evolutionary perspective. Journal of Urban Technology, 18(2), 53-63.

Miles. M.B., \& Huberman, A.M. (1994). Qualitative data analysis: An expanded sourcebook. Sage Publications: New York.

Ministerie van Infrastructuur en Milieu (2016). Programma Slimme \& Gezonde Stad. Retrieved January 10, 2019.

Mooi Boxtel (2017a). Drukke informatiemiddag bij De Kleine Aarde. Retrieved from: https:/www. mooiboxtel.nl/nieuws/algemeen/36850/drukbezochte-informatiemiddag-bij-de-kleine-aarde?redir.

Mooi Boxtel (2017b) 1. 'Gemeente wekt indruk dat Het Collectief moest winnen'. Retrieved from: https://www.mooiboxtel.nl/nieuws/algemeen/36607/-gemeente-wekt-de-indruk-dat-het-collectief-moestwinnen-?related.

Moore, J. F. (1993). Predators and prey: A new ecology of competition. Harvard Business Review, 71, 75-86.

Mora, L., Bolici, R., \& Deakin, M. (2017). Smart City development paths: Insights from the first two decades of research. In A. Bisello, D. Vettorato, P. Laconte, \& S. Costa (Eds.), Smart and sustainable planning for cities and region: Results of SSPCR 2017. Cham: Springer.

Mortara, L., Napp, J. J., Slacik, I., \& Minshall, T. (2009). How to implement open innovation: Lessons from studying large multinational companies. University of Cambridge Institute for Manufacturing.

NOS (2016). Stad van de toekomst. Retrieved December 21, 2018 from: https://nos.nl/op3/artikel/2110214zo-is-het-om-in-een-slimme-stad-te-wonen.html.

Oh, D., Philips, F., Park, S., \& Lee, E. (2016). Innovation ecosystems: A critical examination. Technovation, $54,1-6$.

Paskaleva, K. A. (2009). Enabling the Smart City: The progress of city e-governance in Europe. International Journal of Innovation and Regional Development, 1(4), 405-422.

Pop, O. A., Leroi-Werelds, S., Roijakkers, N., \& Andreassen, T. W. (2018). Institutional types and institutional change in healthcare ecosystems. Journal of Service Management, 29(4), 593-614.

Pullen, A. J. J., de Weerd-Nederhof, P. C., Groen, A. J., \& Fisscher, O. A. M. (2012). Open innovation in practice: Goal complementarity and closed NPD networks to explain differences in innovation performance for SMEs in the medical devices sector. Journal of Product Innovation Management, 29(6), 917934.

Rijksoverheid (2018). 120 miljoen euro voor 'proeftuinen' aardgasvrije wijken in 27 gemeenten. Retrieved January 17, 2019 from: https:/www.rijksoverheid.nl/actueel/nieuws/2018/10/01/120-miljoen-euro-voor$\%$ E2\%80\%98proeftuinen\%E2\%80\%99-aardgasvrije-wijken-in-27-gemeenten.

Robards, M. D., Schoon, M. L., Meek, C. L., \& Engle, N. L. (2011). The importance of social drivers in the resilient provision of ecosystem services. Global Environmental Change, 21, 522-529.

Rosing, K., Frese, M., \& Bausch, A. (2011). Explaining the heterogeneity of the leadership-innovation relationship: Ambidextrous leadership. The Leadership Quarterly, 22(5), 956-974. 
Sandulli, F. D., Ferraris, A., \& Bresciani, S. (2017). How to select the right public partner in smart city projects. R\&D Management, 47(4), 607-619.

Saunders, M., Lewis, P., \& Thornhill, A. (2009). Research methods for business students. Fifth edition. Pearson Education: Essex.

Scaringella, L., \& Radziwon, A. (2018). Innovation, entrepreneurial, knowledge, and business ecosystems: Old wine in new bottles? Technological Forecasting and Social Change, 136, 59-87.

Schaffers, H., Komninos, N., Pallot, M., Trousse, B., Nilsson, M., \& Oliveira, A. (2011). Smart cities and the future internet: Towards cooperation frameworks for open innovation. The Future Internet, 431-446.

Stam, S. (2015). Entrepreneurial ecosystems and regional policy: A sympathetic critique. European Planning Studies, 23(9), 1759-1769.

Shah S. K. (2006) Motivation, Governance, and the Viability of Hybrid Forms in Open Source Software Development. Management Science 52(7):1000-1014.

Thomas, L. D., \& Autio, E. (2014). The processes of ecosystem emergence. In Working Paper, Imperial College Business School, University of London, July.

Usman, M., Roijakkers, N., Vanhaverbeke, W., \& Frattini, F. (2018). A systematic review of the literature on open innovation in SMEs. In: Usman et al. (eds), Researching Open Innovation In Smes, pp. 3-35.

Van Grinsven, J. (2017). 'Bewuste starters' in appartementen op terrein De Kleine Aarde in Boxtel. Retrieved from: https://www.bd.nl/boxtel/bewuste-starters-in-appartementen-op-terrein-de-kleine-aarde-inboxtel a1375e $0 \mathrm{a} /$.

Welter, V. W. (2003). Biopolis: Patrick geddes and the city of life. Cambridge: MIT Press.

Woonstichting Joost (2018). Comfortabel en duurzaam wonen op de Kleine Aarde. Retrieved from: https://www.sintjoseph.nl/comfortabel-en-duurzaam-wonen-op-de-kleine-aarde/

Yin, R. K. (2013). Case study research. Design and methods. Sage Publications Inc: California.

Zeemeijer, I. (2017). Slimme stad is niet in een dag gebouwd. Retrieved December 20, 2018 from: https://fd. $\mathrm{nl} /$ morgen/1218244/slimme-stad-is-niet-in-een-dag-gebouwd.

Publisher's note Springer Nature remains neutral with regard to jurisdictional claims in published maps and institutional affiliations.

\title{
Affiliations
}

\section{Ward Ooms ${ }^{1} \cdot$ Marjolein C. J. Caniëls ${ }^{1} \cdot$ Nadine Roijakkers $^{1} \cdot$ Dieudonnee Cobben ${ }^{1}$}

\author{
Ward Ooms \\ Ward.ooms@ou.nl \\ Nadine Roijakkers \\ nadine.roijakkers@ou.nl \\ Dieudonnee Cobben \\ Dieudonnee.cobben@ou.nl
}

1 Open University of the Netherlands, Heerlen, Netherlands 